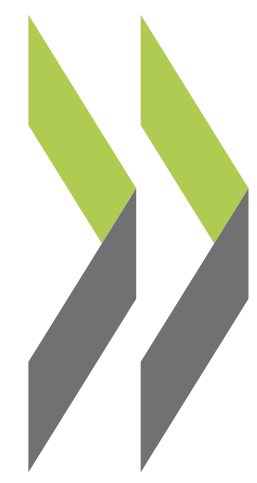

OECD Economics Department Working Papers No. 1436

Getting the most out of trade

Zuzana Smidova,

in Estonia

Naomitsu Yashiro 
Organisation de Coopération et de Développement Économiques

Organisation for Economic Co-operation and Development

23-Nov-2017

ECONOMICS DEPARTMENT

English - Or. English

Cancels \& replaces the same document of 17 November 2017

\section{GETTING THE MOST OUT OF TRADE IN ESTONIA}

ECONOMICS DEPARTMENT WORKING PAPERS No. 1436

By Zuzana Smidova and Naomitsu Yashiro

OECD Working Papers should not be reported as representing the official views of the OECD or of its member countries. The opinions expressed and arguments employed are those of the author(s).

Authorised for publication by Alvaro Pereira, Director, Country Studies Branch, Economics Department.

All Economics Department Working Papers are available at www.oecd.org/eco/workingpapers

JT03423505

This document, as well as any data and map included herein, are without prejudice to the status of or sovereignty over any territory, to the delimitation of international frontiers and boundaries and to the name of any territory, city or area. 
OECD Working Papers should not be reported as representing the official views of the OECD or of its member countries. The opinions expressed and arguments employed are those of the author(s).

Working Papers describe preliminary results or research in progress by the author(s) and are published to stimulate discussion on a broad range of issues on which the OECD works.

Comments on Working Papers are welcomed, and may be sent to OECD Economics Department, 2 rue André-Pascal, 75775 Paris Cedex 16, France, or by e-mail to eco.contact@oecd.org.

All Economics Department Working Papers are available at www.oecd.org/eco/workingpapers.

This document and any map included herein are without prejudice to the status of or sovereignty over any territory, to the delimitation of international frontiers and boundaries and to the name of any territory, city or area.

The statistical data for Israel are supplied by and under the responsibility of the relevant Israeli authorities. The use of such data by the OECD is without prejudice to the status of the Golan Heights, East Jerusalem and Israeli settlements in the West Bank under the terms of international law.

\section{(c) OECD (2017)}

You can copy, download or print OECD content for your own use, and you can include excerpts from OECD publications, databases and multimedia products in your own documents, presentations, blogs, websites and teaching materials, provided that suitable acknowledgment of OECD as source and copyright owner is given. All requests for commercial use and translation rights should be submitted to rights@oecd.org 


\section{ABSTRACT/RÉSUMÉ}

\section{Getting the most out of trade in Estonia}

Estonia is highly integrated into the global trade system: it exports approximately $80 \%$ of GDP and around half of domestic employment is sustained by foreign demand. Given that international trade and foreign direct investment are considered as major channels of technology diffusion and productivity growth, this bodes well for reviving income convergence. To capitalize on the country's high trade intensity, policymakers need to remove remaining trade barriers and improve policies fostering knowledge diffusion as well as talent retention and attraction. At the same time, to ensure that benefits of more trade are shared across the population, the social safety net should be bolstered, and participation in upskilling programmes and their labour-market relevance increased.

This Working Paper relates to the 2017 OECD Economic Survey of Estonia (www.oecd.org/eco/surveys/economic-survey-estonia.htm).

JEL classification: F22, F43, F63, F68, I 31, O24, O52

Keywords: Estonia, international trade, global value chains, productivity, innovation, migration, social safety net

\section{Tirer le meilleur parti des échanges en Estonie}

L'Estonie, qui exporte environ $80 \%$ de son PIB et tire près de la moitié de ses emplois nationaux de la demande étrangère, est très bien intégrée dans le système commercial international. Les échanges internationaux et l'investissement direct étranger étant considérés comme des canaux majeurs de diffusion de la technologie et de hausse de la productivité, cette performance augure bien de la reprise de la convergence des revenus. Pour tirer le meilleur profit de la forte intensité des échanges qui caractérise le pays, les responsables de l'action publique doivent lever les obstacles aux échanges qui perdurent et améliorer les politiques publiques visant à favoriser la diffusion de la connaissance ainsi qu'à mieux attirer et retenir les talents. Parallèlement, pour s'assurer que les fruits d'une intensification des échanges soient partagés par toute la population, il conviendrait de développer le système de protection sociale, ainsi que de relever la participation aux programmes de valorisation des compétences et d'en accroître la pertinence pour le marché du travail.

Ce Document de travail se rapporte à l'Étude économique de l'OCDE de l'Estonie 2017 (www.oecd.org/fr/eco/etudes/etude-economique-estonie.htm).

Classification JEL: F22, F43, F63, F68, I 31, O24, O52

Mots clefs: Estonia, commerce international, chaines de valeur mondiales, productivité, innovation, migration, sécurité sociale 


\section{TABLE OF CONTENTS}

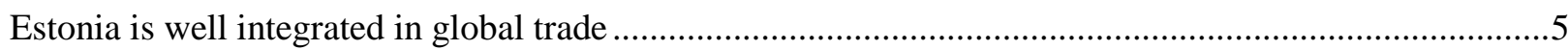

Policies can further deepen integration in global trade and boost productivity .....................................13

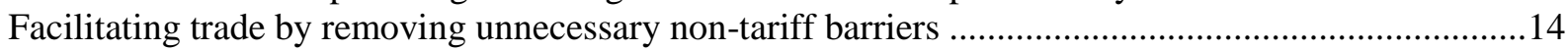

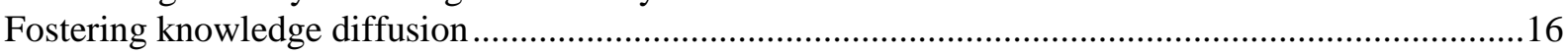

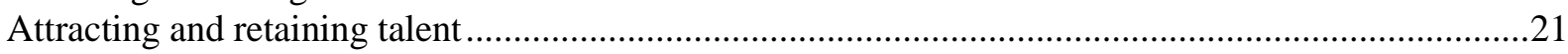

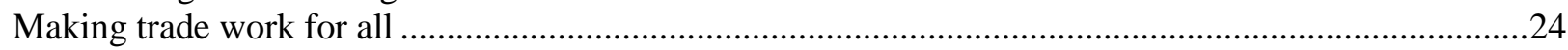

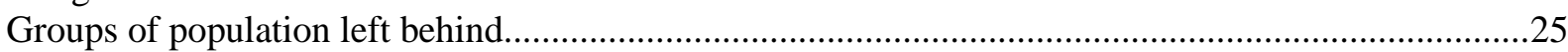

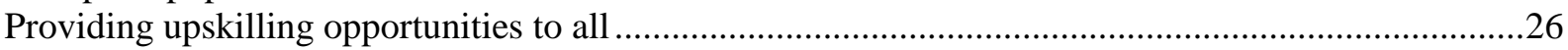

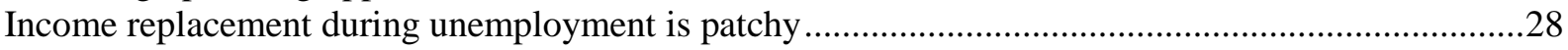

The social safety net has improved but needs further strengthening...................................................

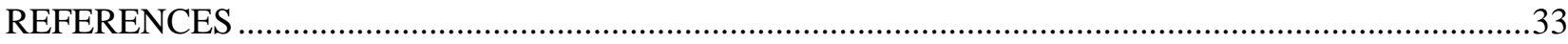

\section{Tables}

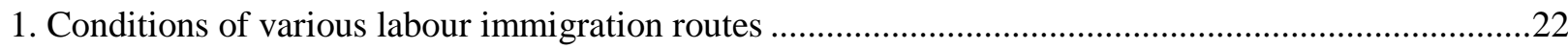

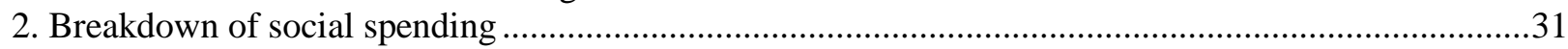

\section{Figures}

1. Export orientation and gains in export market shares are comparable to peers ....................................6

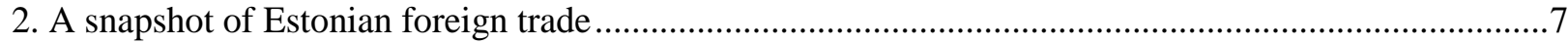

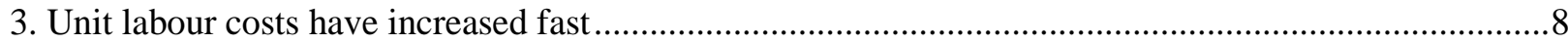

4. Estonia is well integrated into global value chains and mostly as a service provider............................9

5 Exporters could import more value added from abroad........................................................................10

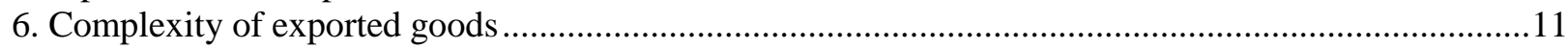

7. Employment in exports of higher value added activities increased modestly .....................................12

8. Domestic value added of exports remains limited though on a par with peer countries.........................13

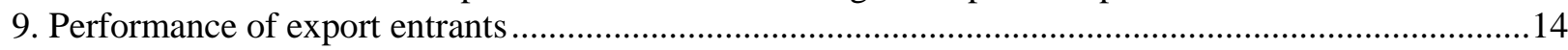

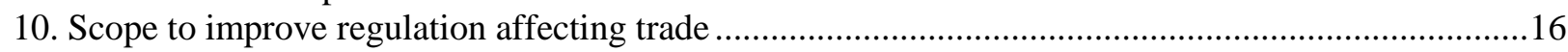

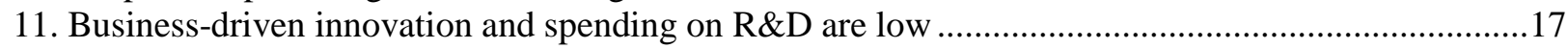

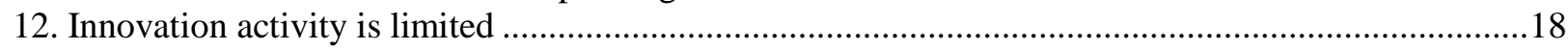

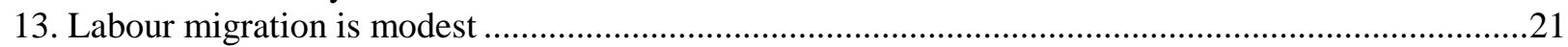

14. Annual quota were reached recently, while the number of highly skilled migrants is modest............23

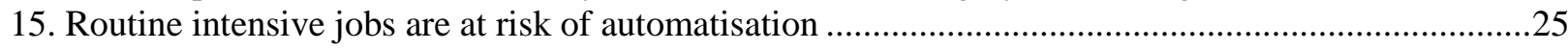

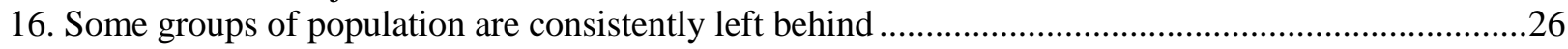

17. Businesses are little involved in the provision of vocational education and training ........................28

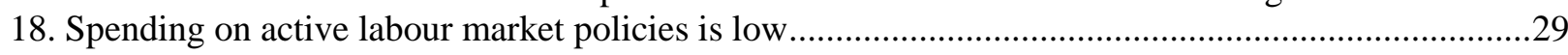

19. The share of social benefits received by the poor is low and has declined............................................

\section{Boxes}

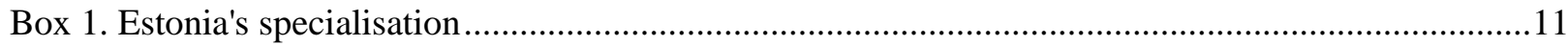

Box 2. Higher productivity of exporters - Estonian firm-level data analysis ..........................................14

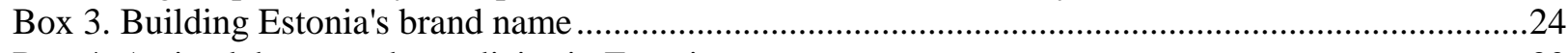

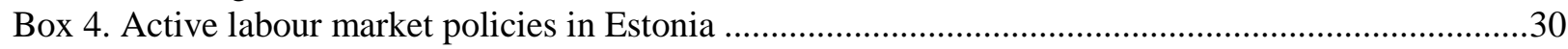

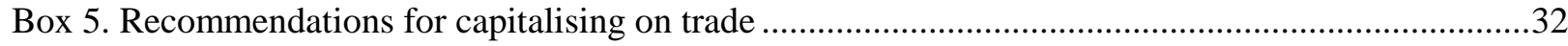




\title{
GETTING THE MOST OUT OF TRADE IN ESTONIA
}

\author{
by Zuzana Smidova and Naomitsu Yashiro ${ }^{1}$
}

International trade and foreign direct investment are major channels of technology diffusion and productivity growth, as is participation in global value chains (Keller and Yeaple, 2009, Baldwin, 2012, Rusticelli et al., 2017). Exporters display higher productivity and innovation, and Estonian firms are no exception (Masso and Vahter, 2015, Benkovskis et al, 2017 forthcoming). These features will support the country's catch up in productivity, and its sustainable convergence. At the same time, high trade intensity means fast transmission of global trends and shocks, which can result in job losses, requiring robust social safety net and adjustment policies.

This chapter looks at how Estonia can better capitalize on its current trade involvement while ensuring that the benefits are shared across the whole population. The chapter starts by examining the participation of Estonian firms in trade and global value chains (GVCs), before turning into a more detailed discussion of trade barriers, policies for knowledge diffusion and retaining and attracting talent. It then looks into policies for ensuring that the benefits of increased trade intensity are shared widely across the population.

\section{Estonia is well integrated in global trade}

With exports at around $80 \%$ of GDP, Estonia's integration into global trade is high and on a par with comparable European catching-up economies (Figure 1). Given the small size of the domestic market, exporting is a natural business development step for Estonian companies. Around 12\% of firms export, while in OECD countries less than $10 \%$ of firms are directly engaged in international trade (OECD, 2016a). Additionally, around a half of private sector employment is sustained by foreign demand, twice as much as the OECD average (OECD, 2016b).

1. Zuzana Smidova (Zuzana.smidova@oecd.org) and Naomitsu Yashiro (Naomitsu.Yashiro@oecd.org) are members of the OECD Economics Department (ECO). Zuzana Smidova would like to thank Caroline Klein, David Haugh and Pierre Beynet, (ECO) for their valuable comments and suggestions, also to Veiko Lember, Public Governance Institute, KU Leuven, Belgium and Ragnar Nurkse Department of Innovation and Governance, Tallinn University of Technology, Estonia. for background research on the state of innovation in Estonia. Special thanks go to Corinne Chanteloup for research assistance and Heloise Wickramanayake (ECO) for editorial support. 
Figure 1. Export orientation and gains in export market shares are comparable to peers
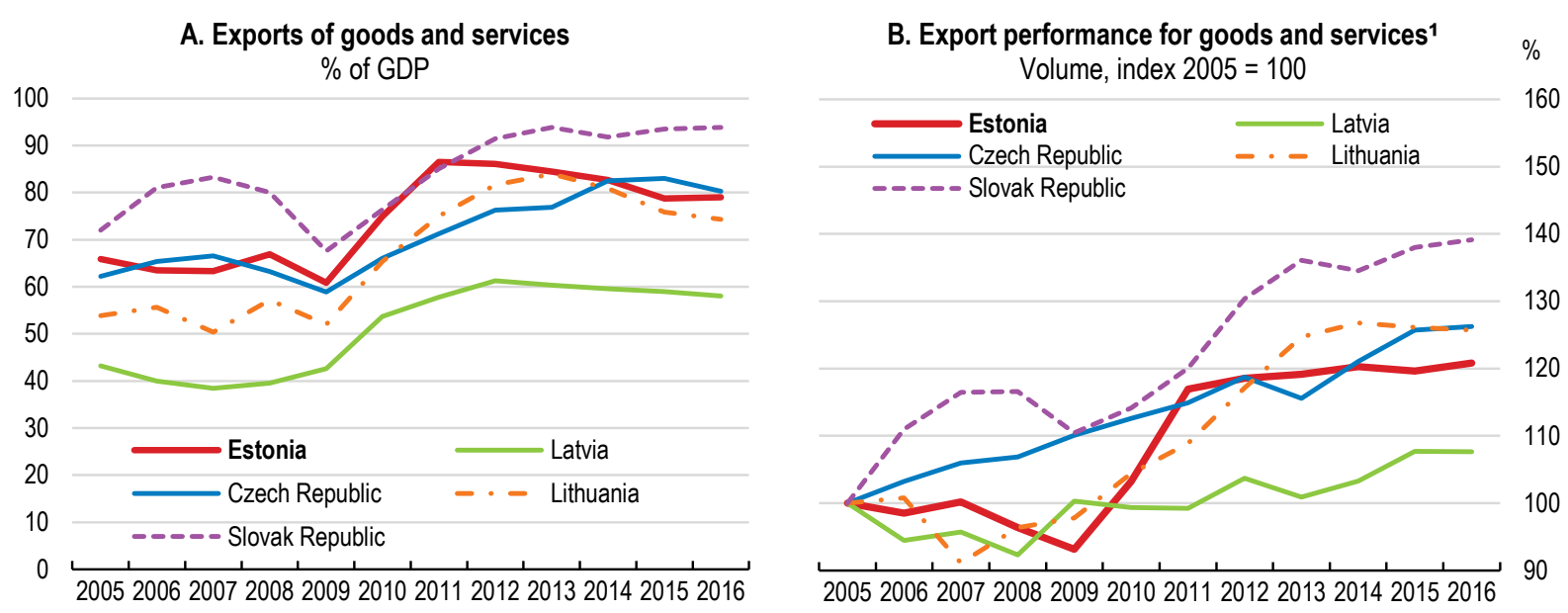

1. Export performance is measured as actual growth in exports relative to the growth of the country's export market.

Source: OECD Economic Outlook 101 database (updated with information available on 1 September 2017).

Export market shares of Estonian exporters doubled since 1995, with roughly equal shares of intermediate and final goods. Primary-sector exports steadily declined while the role of services steadily increased. Services account for $40 \%$ of export volumes and over $60 \%$ of value-added, with maritime transport and tourism the largest items. Electronic equipment, wood and wood products and agriculture products are the main exported goods and amount to $41 \%$ of total exports of goods (Figure 2, Panel D). The EU was the destination for 74\% of Estonian exports in 2016, with neighbouring Sweden, Finland, Latvia and Lithuania being the main destinations (Figure 2, Panel C). Russia also remains among Estonia's main trading partners despite a significant trend decline in trade between the two countries over past decades.

A significant upward shift in export performance followed the financial crisis, underpinned by a substantial wage adjustment, labour shedding and diversification of exports destinations, but growth in volumes and gains of market shares have since been more moderate (Figure 1). The slowdown in the growth of export market shares of recent years may reflect the difficult economic conditions of Finland and Russia, two important trading partners, falling exports of oil-shale (Eesti Pank, 2016), and a deterioration of price and non-price competitiveness. At 12\% exports growth in the first quarter of 2017 was however promising. 
Figure 2. A snapshot of Estonian foreign trade

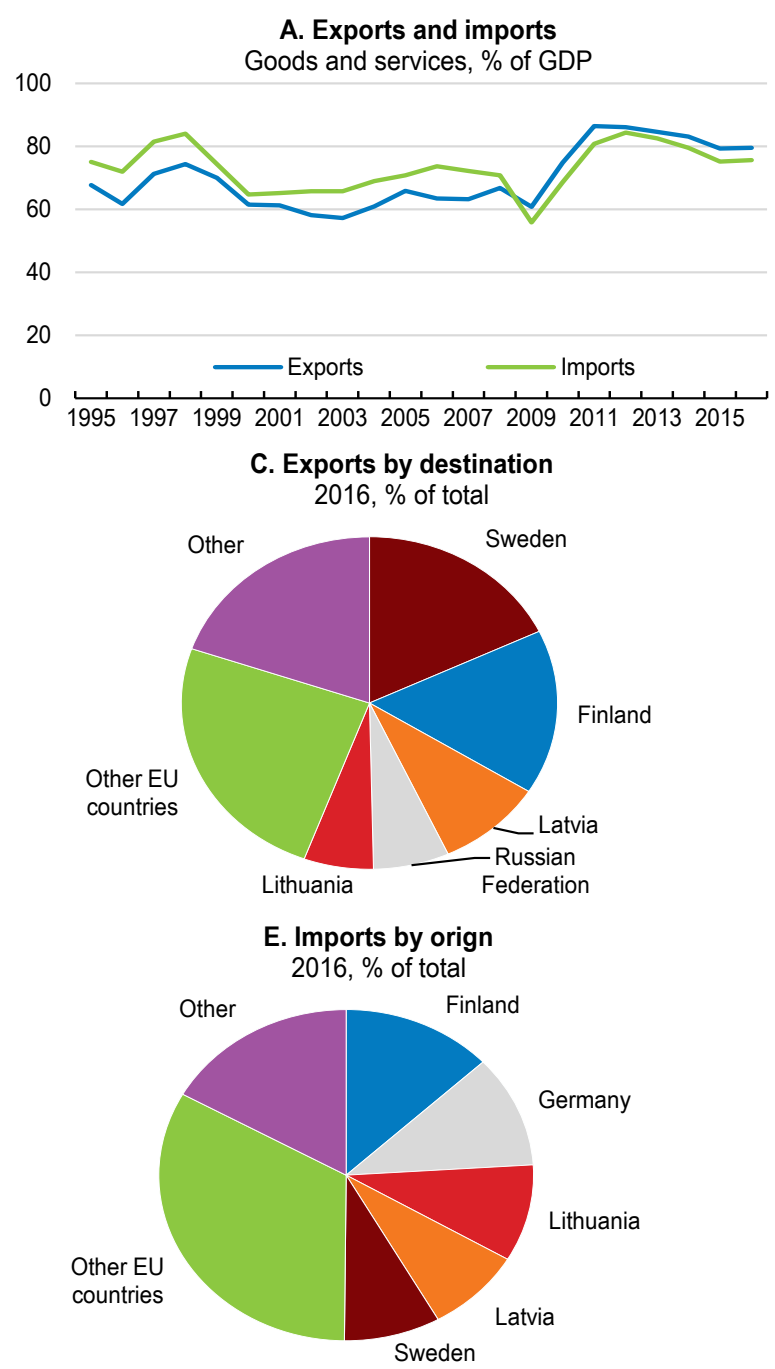

B. Trade openess

Exports plus imports, \% of GDP, 2016

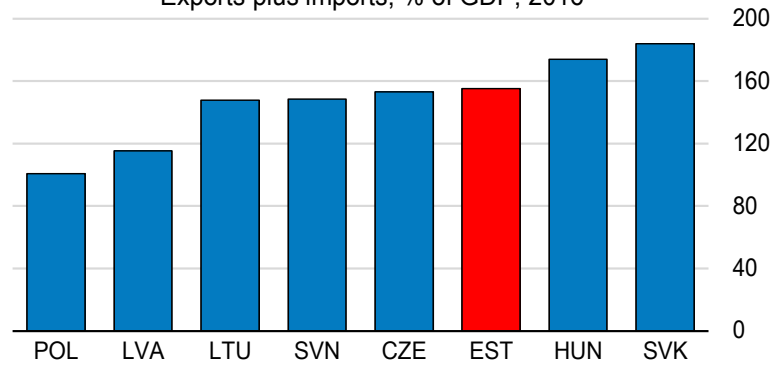

D. Exports by product
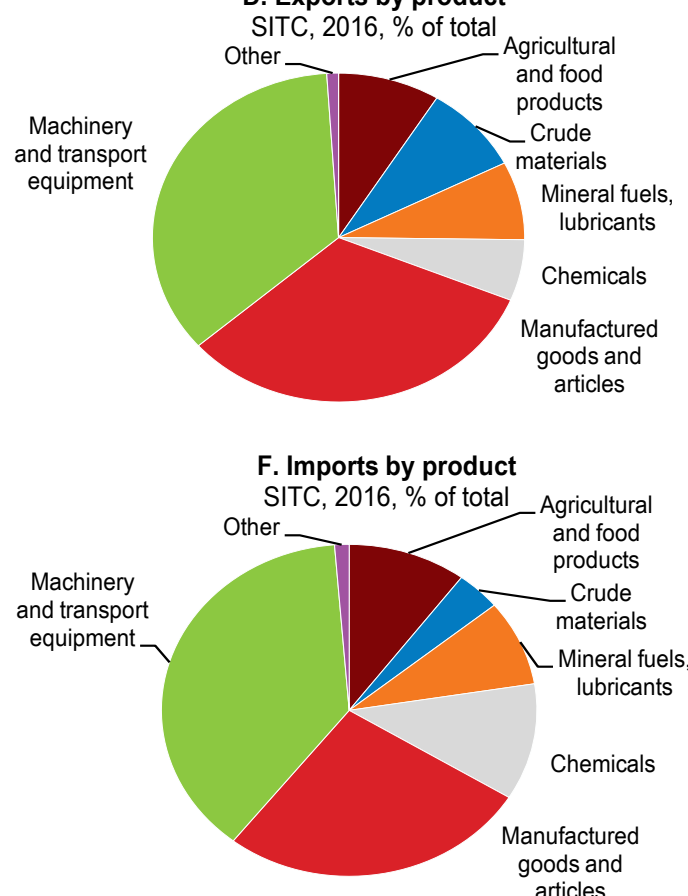

H. Imports by type of services $2016, \%$ of total

G. Exports by type of services $2016, \%$ of total
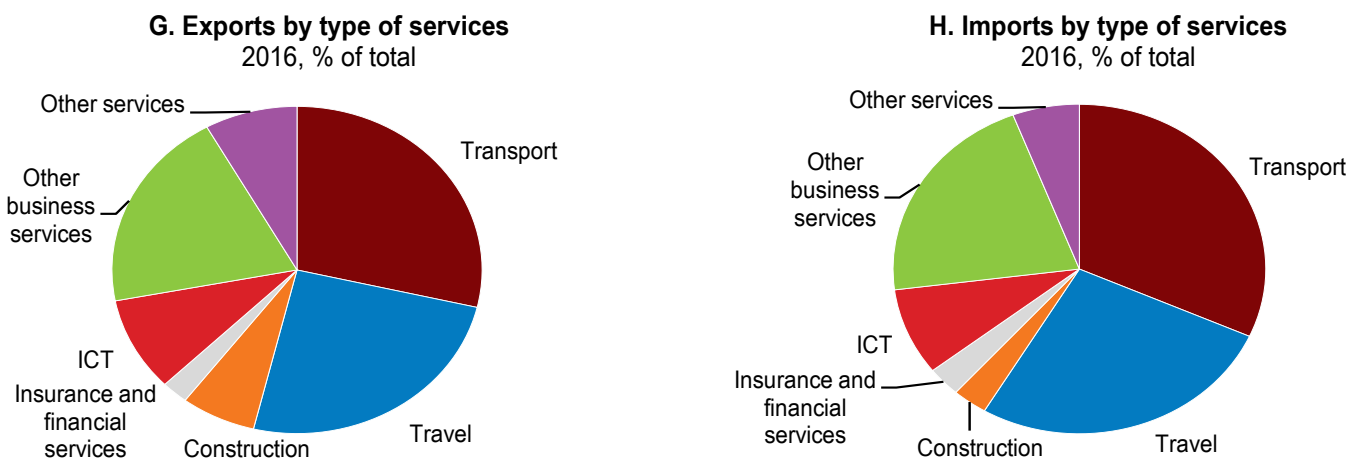

Source: OECD Economic Outlook 101 database, Bank of Estonia and Statistical Office of Estonia.

Wages have increased considerably in recent years, meaning that workers are benefitting from the recovery, and while this is to be expected in a catching-up economy it has put pressure on profit margins of firms. The wage growth of recent years has become disconnected from stagnating productivity growth raising some concern for price competitiveness (IMF, 2017; EC, 2016). Such developments in unit labour 
costs cannot be fully attributed to structural shifts in the economy and the catching-up process. Relative unit labour costs grew by over $30 \%$ since 2005, the biggest increase among the Central European and Baltic peers (Figure 3). Wage increases in the government sector and of the minimum wage also played a considerable role (IMF, 2017). Over the past five years, the minimum wage increased consecutively five times by $10 \%$, while public sector wages grew on average by $8 \%$ annually. While emigration of skilled labour puts upwards pressure on wages, Estonia has been less affected by brain drain than its Baltic peers and the net emigration to neighbouring Nordic countries with higher income levels has reversed since 2015 (IMF, 2016). Maintaining price competitiveness can prove challenging going forward as the decline in the working age population and emerging shortages of skilled workers will keep wage pressures high.

Since Estonian exporters are by and large price-takers in world markets, increases in labour costs reduce their profit margins. Enterprise data confirm pressure on profits in the tradable sector. In manufacturing, profitability is close to a half of its historical average, while in the non-tradable sector it is close to its long-term average; this is consistent with diminishing competitiveness (IMF, 2017). When reductions in profit margins are no longer possible, labour is substituted by capital, which would be in line with increasing productivity of the economy and the general catching-up process. However, this has not been happening. Moreover, reduction in margins can also impede capital spending by reducing available internal funds (see Chapter 2).

Figure 3. Unit labour costs have increased fast
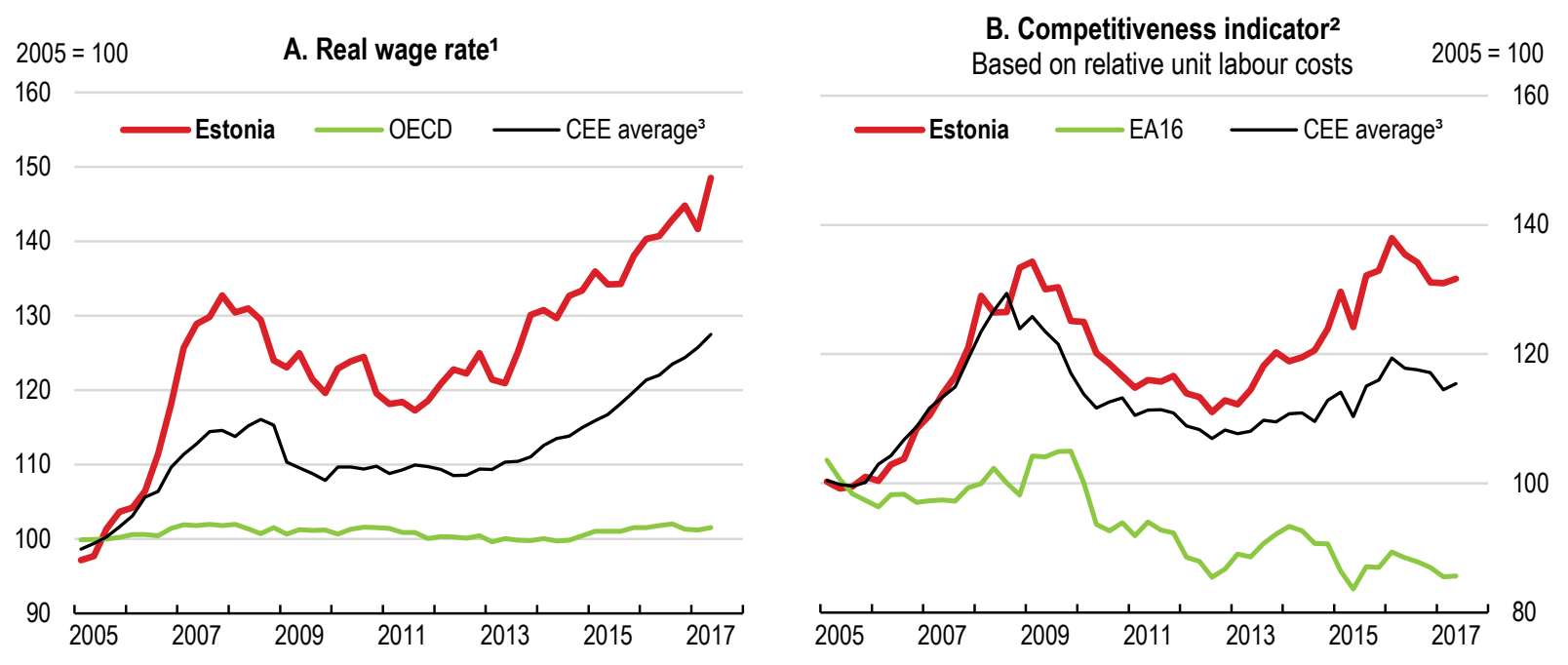

1. Deflated by the consumer price index.

2. An increase in the index indicates a real appreciation and a corresponding deterioration of the competitive position.

3. Simple average of Czech Republic, Hungary, Latvia, Lithuania, Poland, Slovak Republic, and Slovenia.

Source: OECD Economic Outlook 101 database (updated with information available on 01 September 2017).

Quality improvements matter too. A number of emerging economies have been able to grow exports despite catching up in terms of prices (e.g. China), while other countries that have improved cost competitiveness have not seen an increase in their global market shares in recent years (Benkovskis and Woertz, 2016). Based on an index accounting for these non-price competitiveness aspects (such as product quality and consumer tastes), Benkovskis and Woertz (2016) show that over 2000-2012 the non-price competitiveness of Estonian exports has not changed much, while it has improved considerably for several European peers. Another analysis of non-price competitiveness development paints a less bleak picture 
(Eesti Pank, 2017). To date, despite these developments Estonia has continued to increase its share of world exports (see Figure 1, Panel B), suggesting that a one-off squeezing of profit margins and other factors such as quality not captured by available data have sustained Estonia's export performance and increased the share of labour's returns to international trade. However, now that the potential for further reducing margins seems more limited, vigilance to ensure wages are in line with productivity is required.

Global value chains (GVCs) have become a dominant feature of world trade and investment, and participation in GVCs appears to be associated with productivity gains (OECD, 2013; IMF, 2013). Estonia seems well integrated in the global value chains, on a par with it its European peers (e.g. Latvia, Slovakia and the Czech Republic) (Figure 4 and 5). Over $40 \%$ of its value added is embodied in foreign demand (socalled forward participation) and that is largely created in the service sector, notably logistics and business services (Figure 4). Within manufacturing, Estonia's value added is mostly created by traditional industries such as wood processing and chemicals and basic metal products, but also electronics.

Figure 4. Estonia is well integrated into global value chains and mostly as a service provider

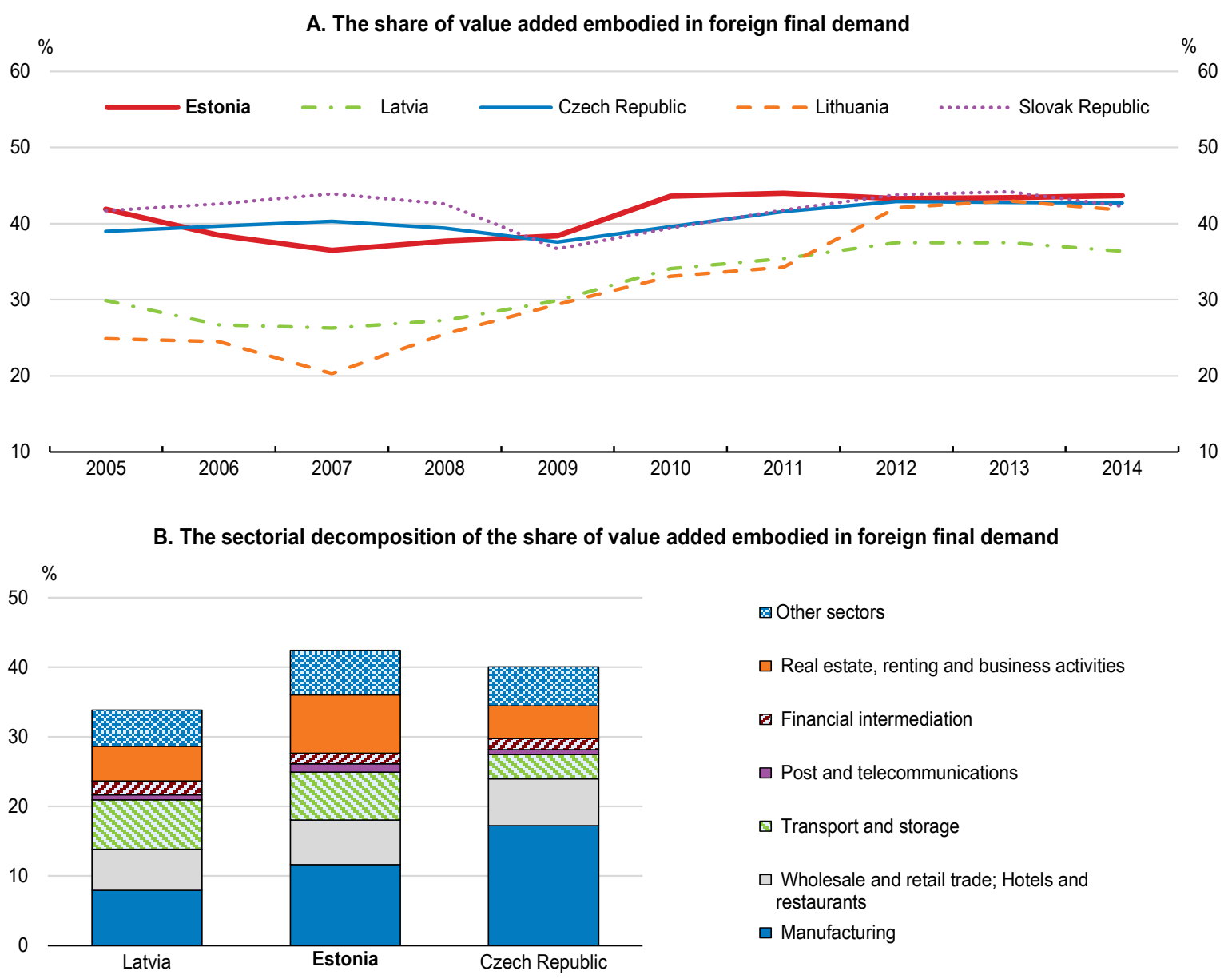

Note: Panel A displays the share of domestic value added that are embodied in the foreign final demand in total domestic value added. The data after 2011 are estimates based on the 2011 Inter-Country Input-Output (ICIO) table and the OECD Bilateral Trade Database by Industry and End-Use (BTDIXE). Panel B is a sectoral break down of the share shown in panel A. It refers to the 2011 data.

Source: OECD/WTO (2016), Statistics on Trade in Value Added (database), and OECD calculations based on OECD/WTO (2016), Statistics on Trade in Value Added (database) and OECD (2016), OECD National Accounts Statistics (database). 
In terms of so-called backward participation, or the country's participation in GVCs as a "user", there seems to be a scope for upgrading of domestic production by importing more (Figure 5). Using more technologically advanced foreign intermediate goods can boost domestic productivity by upgrading product quality and absorbing the knowledge embodied in intermediate goods (Amiti and Konings, 2007). Also, export competitiveness is linked to ability to access competitively priced intermediates (Kowalski et al., 2015).

Figure 5. Exporters could import more value added from abroad

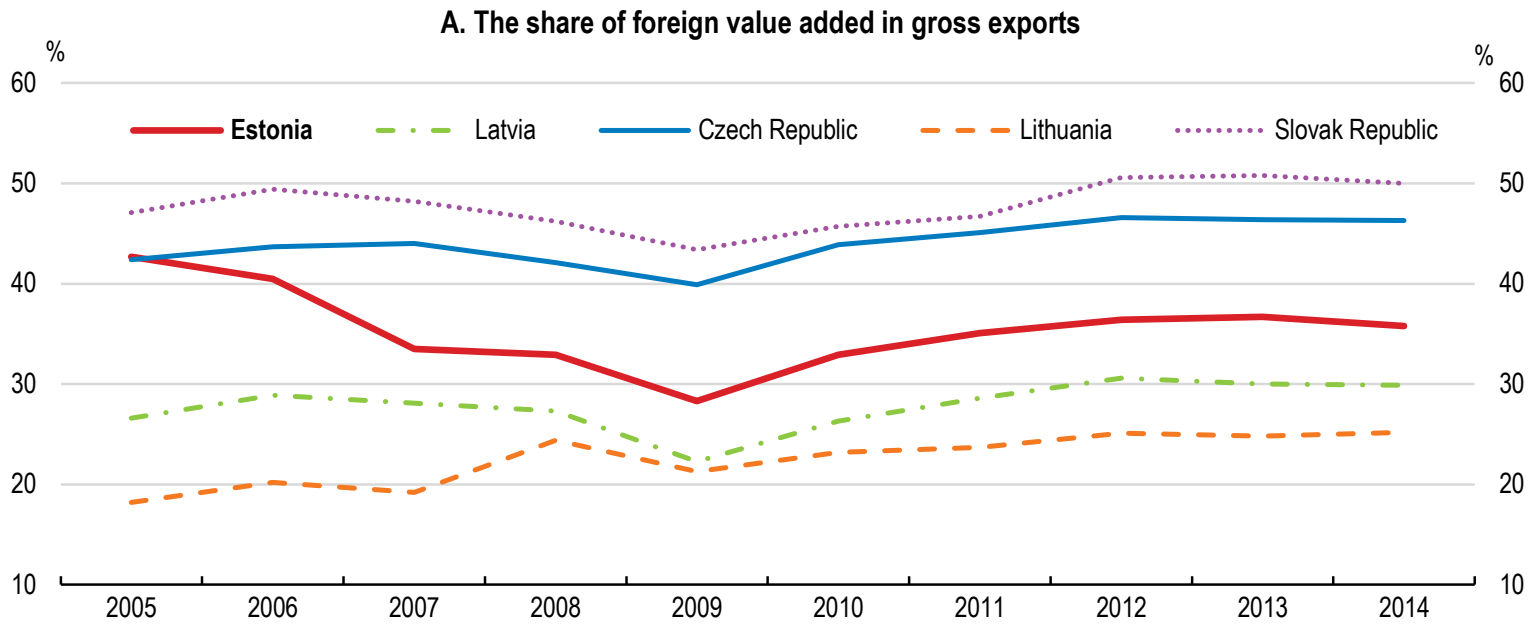

B. Industrial decomposition of the share of foreign value added in manufacturing exports

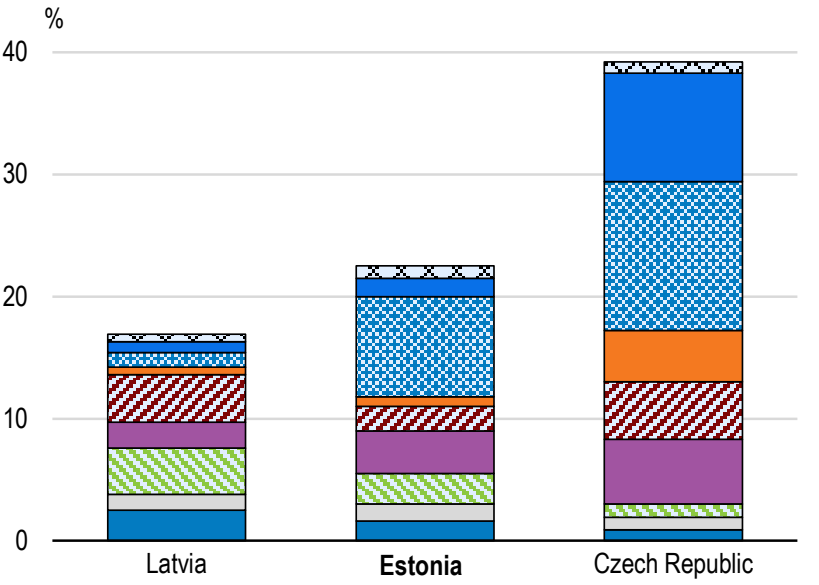
๑ Manufacturing nec; recycling
$\square$ Transport equipment
曰Electrical and optical equipment
$\square$ Machinery and equipment, nec
$\checkmark$ Basic metals and fabricated metal products
$\square$ Chemicals and non-metallic mineral products
$\square$ Wood, paper, paper products, printing and publishing
$\square$ Textiles, textile products, leather and footwear
$\square$ Food products, beverages and tobacco

Note: Panel A displays the share of foreign value added that are embodied in the country's exports. The data after 2011 are estimates based on the 2011 Inter-Country Input-Output (ICIO) table and the OECD Bilateral Trade Database by Industry and End-Use (BTDIxE). Panel B is the breakdown of such share focusing only on the exports in manufacturing sector. It refers to the 2011 data.

Source: OECD/WTO (2016), Statistics on Trade in Value Added (database), and OECD calculations based on OECD/WTO (2016), Statistics on Trade in Value Added (database) and OECD (2016), OECD National Accounts Statistics (database). 


\section{Box 1. Estonia's specialisation}

Estonian exporters of goods show revealed comparative advantage, a measure of international trade specialisation, in agricultural and food products and manufacturing (in particular machinery and transport equipment) and still mainly in low and medium - technology industries. When estimating complexity of exports by so-called implied productivity, calculated by taking a weighted average of per capita GDPs of the countries that export the product and ranking products according to this implied productivity, Estonia's exports of goods is comparable to its Baltic neighbors but lagging behind the Czech Republic and Slovakia (Figure 6) (Hausmann et al, 2007). This kind of analysis is not available for services that represent an important share of Estonia's exports (see main text).

\section{Figure 6. Complexity of exported goods}

Share of exports by complexity quartile ${ }^{1}$, value

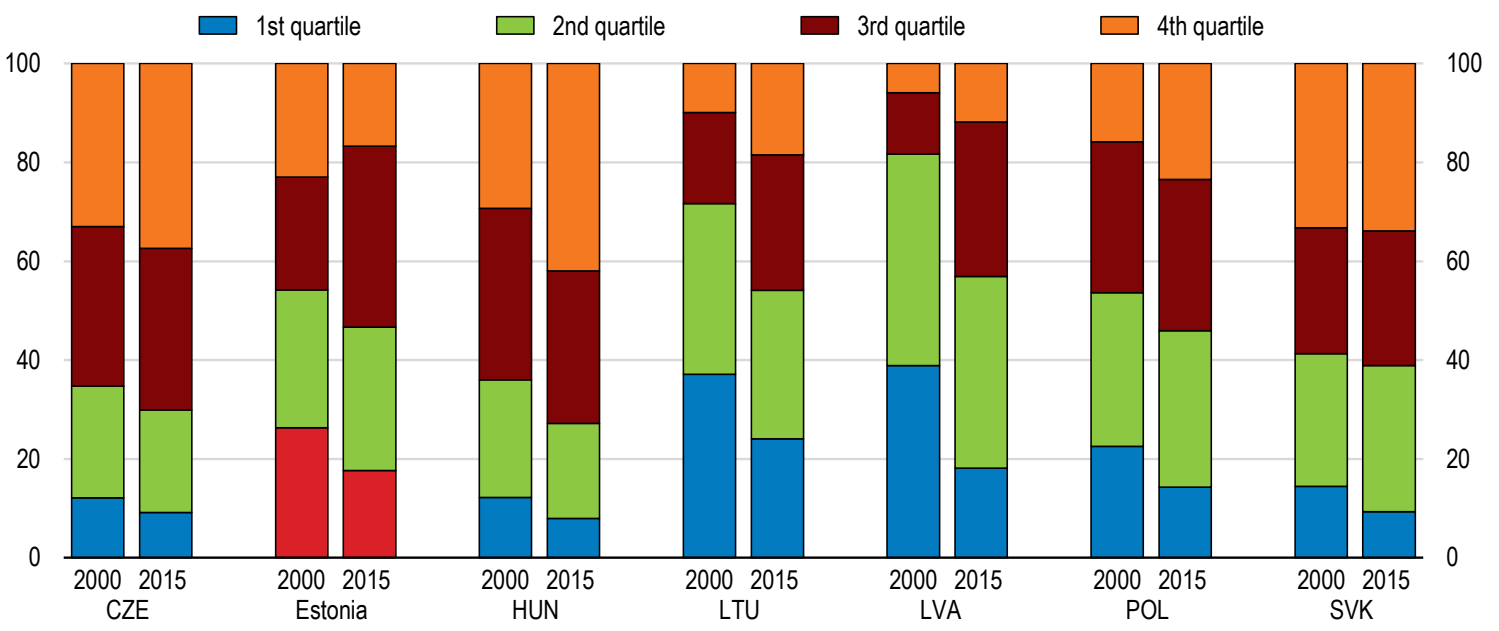

1. Complexity is defined by the implied productivity of the product using the methodology of Hausmann, R., J. Hwang and D. Rodrik (2007), "What you export matters", Journal of Economic Growth, Springer, Vol. 12. It is calculated by taking a weighted average of per capita GDPs of the countries that export the product. The weights are the revealed comparative advantage of each country in that product. The products are then ranked according to their PRODY level. An example of product in the 4th (highest) quartile is magnetic imaging resonance (MRI) machines used in scans in hospitals which ranked 18th in 2015, out of 4989 products listed in the Harmonized System 6 classification. A product in the 1st (lowest) quartile is crayons ranked 4218th in 2015. The analysis is carried out using a high level of product disaggregation to try to capture specialisation at different stages of the production chain. Nevertheless the data are measured in terms of gross value and not value added as would be used in measures of global value chains (GVCs).

Source: UN Comtrade database; and OECD calculations.

Countries supplying knowledge-intensive inputs such as $\mathrm{R} \& \mathrm{D}$, core parts and components or marketing services are remunerated disproportionally more than those providing standardised labour intensive inputs such as assembly services (OECD, 2013). Examining changes in employment shares of different business functions can offer an estimation of whether a country is "moving up the value chain" (Miroudot, 2016). This is illustrated by so-called "smiley curves", whereby a "smile" occurs when the occupations embodied in exports have moved from operation (in the middle of the curve and the valueadded chain) to R\&D, engineering and related technical services (located upstream and on the left of the chart) and/or to transport, logistics, distribution, marketing and sales (located downstream and on the right of the chart), both of which are more knowledge intensive and have higher value added. By this measure, there has been a modest increase in employment of high-skilled workers and a small decrease in the share 
of low and medium-skilled employment over 2000-2011 in Estonia (Figure 7). This is comparable to the Czech Republic and Latvia, though less pronounced than in Slovak Republic.

Figure 7. Employment in exports of higher value added activities increased modestly

$2000-2011$
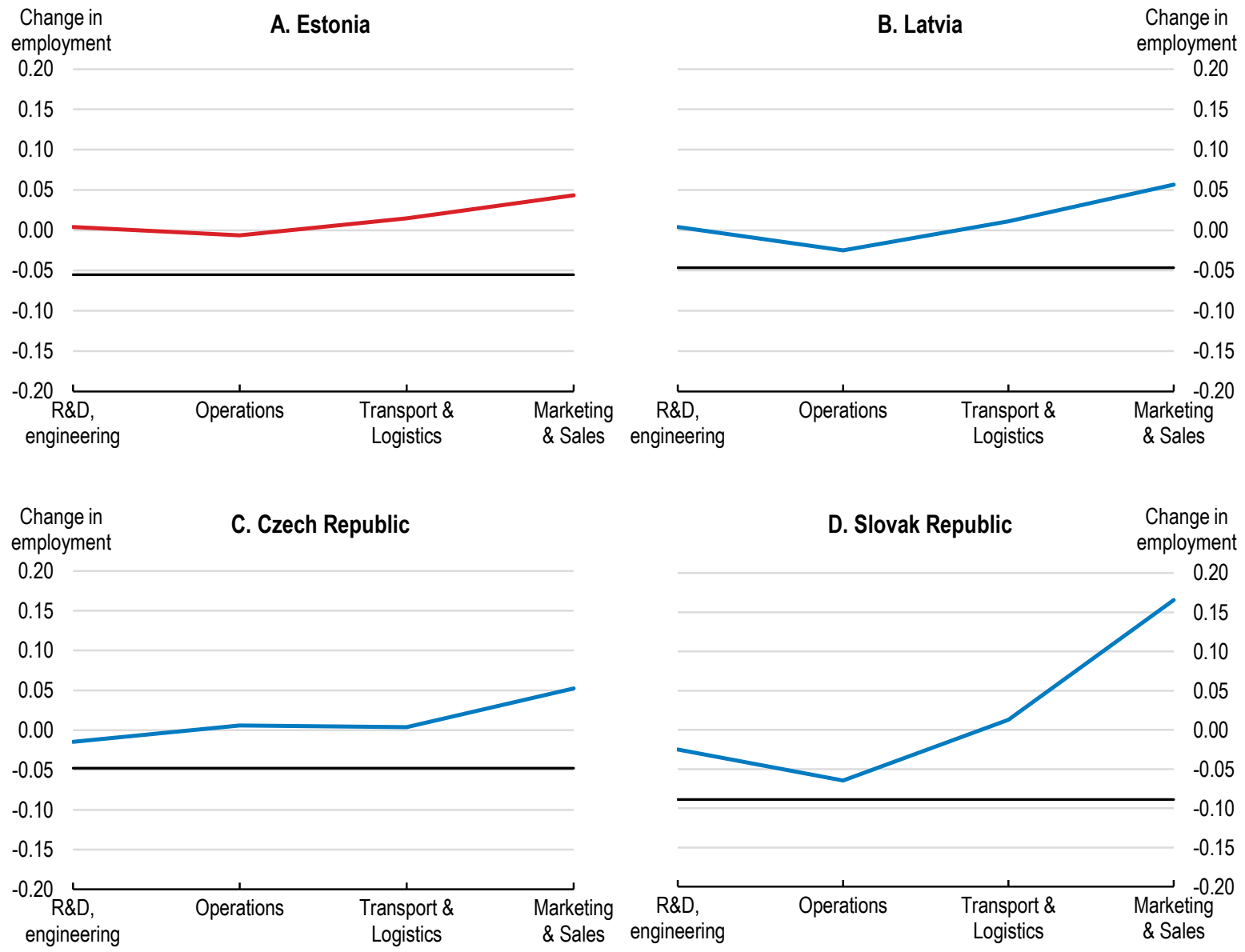

Note: The straight line refers to the change in employment in horizontal support activities (i.e. support IT services, management, administration and back office etc.) The jobs lost in operations are replaced by jobs either in upstream (pre-production) or downstream (post-production) in the value chain.

Source: OECD calculations, update of Miroudot (2016).

Around a half of exported goods are products with lower complexity and while this is comparable to the Baltic peers, the Czech Republic and Slovakia export more sophisticated products (Box 1). Also, though comparable to the peer countries, Estonia is drawing a limited value added per worker from the trade participation compared to many OECD countries, suggesting that indeed, it specialises in low-value added activities (Figure 8, Panel A). There is a large potential for catching up in terms of overall economic productivity too (Figure 8, Panel B). 
Figure 8. Domestic value added of exports remains limited though on a par with peer countries
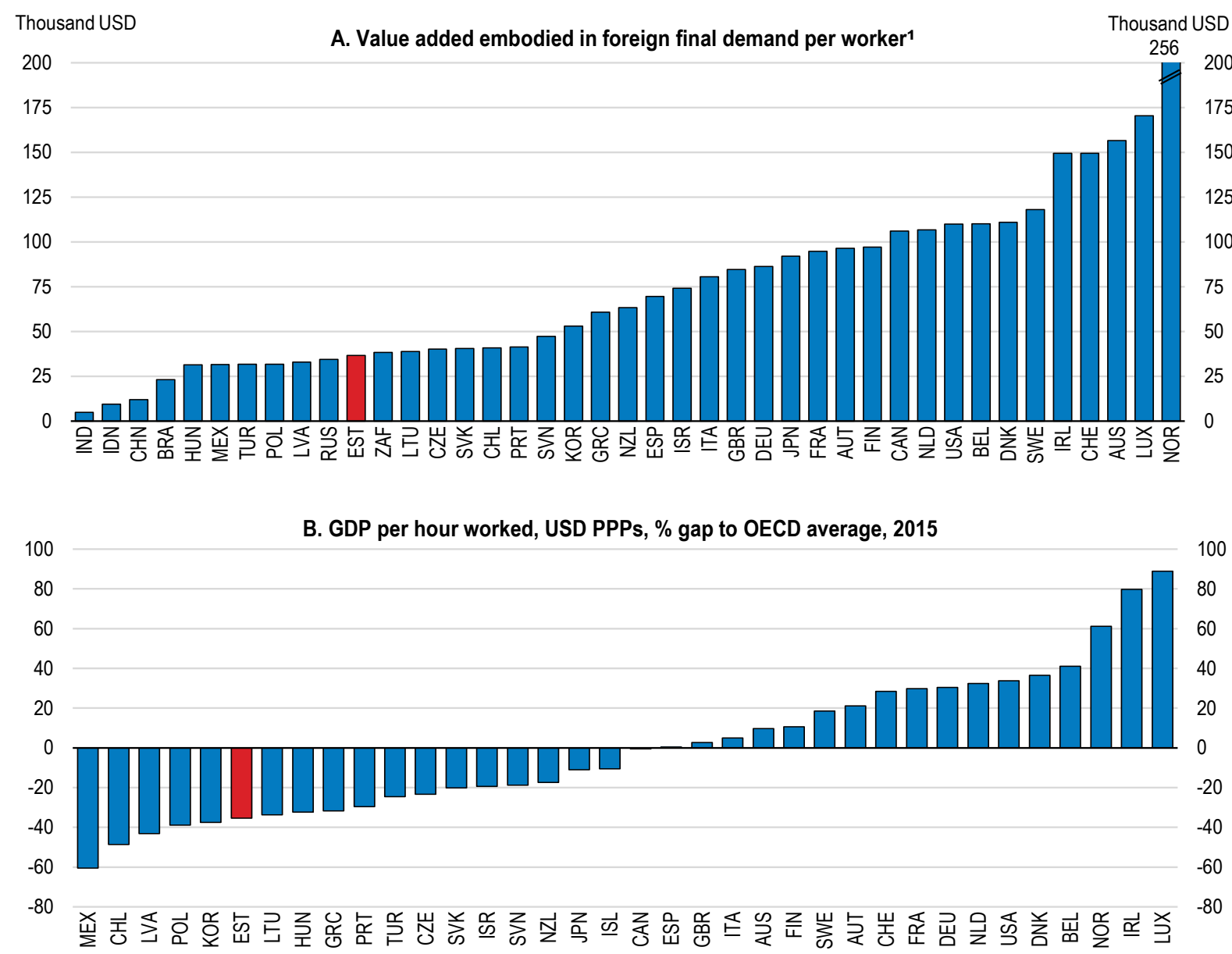

1. Value added embodied in foreign final demand per worker is computed by dividing the domestic value added captured from foreign final demand by the number of employees sustained by foreign final demand. Figure refers to 2011 data.

Source: OECDNTO (2016), Statistics on Trade in Value Added (database) and OECD (2016), "Trade in Employment: Core Indicators" in OECD Structural Analysis (STAN) Databases; OECD Productivity Database.

\section{Policies can further deepen integration in global trade and boost productivity}

Deepening integration in global trade can contribute to reducing the currently high productivity gap with OECD's best performing countries, since exporters tend to have higher productivity, be it a result of 'self-selection' or 'learning-by-exporting' (Bernard and Jensen, 1999, Masso and Vahter, 2015, Benkovskis et al, 2017, forthcoming). Estonian exporters display higher productivity, as well as higher tendency to innovate (Box 2). Climbing up the value chain and finding new export markets is a complex task, underpinned by both policy and non-policy factors such as geographical location and structure of the economy for instance that can be difficult to influence and to overcome. Policies need to focus on trade facilitation, and increasing productivity across the board by fostering better knowledge diffusion in the economy and retaining and attracting talent. 


\section{Box 2. Higher productivity of exporters - Estonian firm-level data analysis}

Exporting firms are found to have a considerably higher productivity level than non-exporting ones, but a large range of studies show that this premium primarily reflects a selection bias: only the most productive firms can enter export markets as there are sunk costs associated with exporting that have to be met (Wagner 2007, 2011; Greenaway and Kneller, 2007; Foster-McGregor et al., 2014). Other studies, however, find that export entry itself has positive impact on productivity even after controlling for this selection bias (Blalock and Gertler 2004; van Biesebroeck 2005; Aw et al. 2007), suggesting that exporting involves knowledge transfer from foreign buyers that improves productivity, or "learning-by-exporting'. The positive impact of export entry is also found to be larger for exports to more advanced countries (de Loecker, 2007) or to multiple markets of multiple products (Masso and Vahter, 2015).

Masso and Vahter (2015) have shown that export entry indeed boosts the productivity of Estonian firms. Based on an analysis of firm-level dataset of 1995-2014 of Latvian and Estonian firms Benkoviskis et al. (2017) confirmed such effect on productivity even when controlling for the self-selection. Figure 9 depicts the difference in gains in labour productivity between Estonian firms that started exporting and of non-exporters that initially shared similar productivity level as well as other characteristics such as size in terms of employees and age. The productivity of export entrants increases by $14 \%$ in the year of export entry and the higher productivity level against non-exporters persists for several years. Employment also increases by up to $10 \%$ and wages by up to $7 \%$ within three years of export entry.

The analysis also shows that exports that are closely related to GVC participation such as exports of intermediate goods, re-exporting and service exports are associated with significant productivity growth (Benkovskis et al, 2017, forthcoming). Masso et al. (2015) and Masso and Vahter (2016) illustrate that the probability that a company will start exporting is higher when it hires managers and top specialists with prior export experience and when it increases the share of employees or managers with experience from multinational firms. Furthermore, exporting firms have higher tendency to innovate (Benkovskis et al, 2017).

\section{Figure 9. Performance of export entrants}

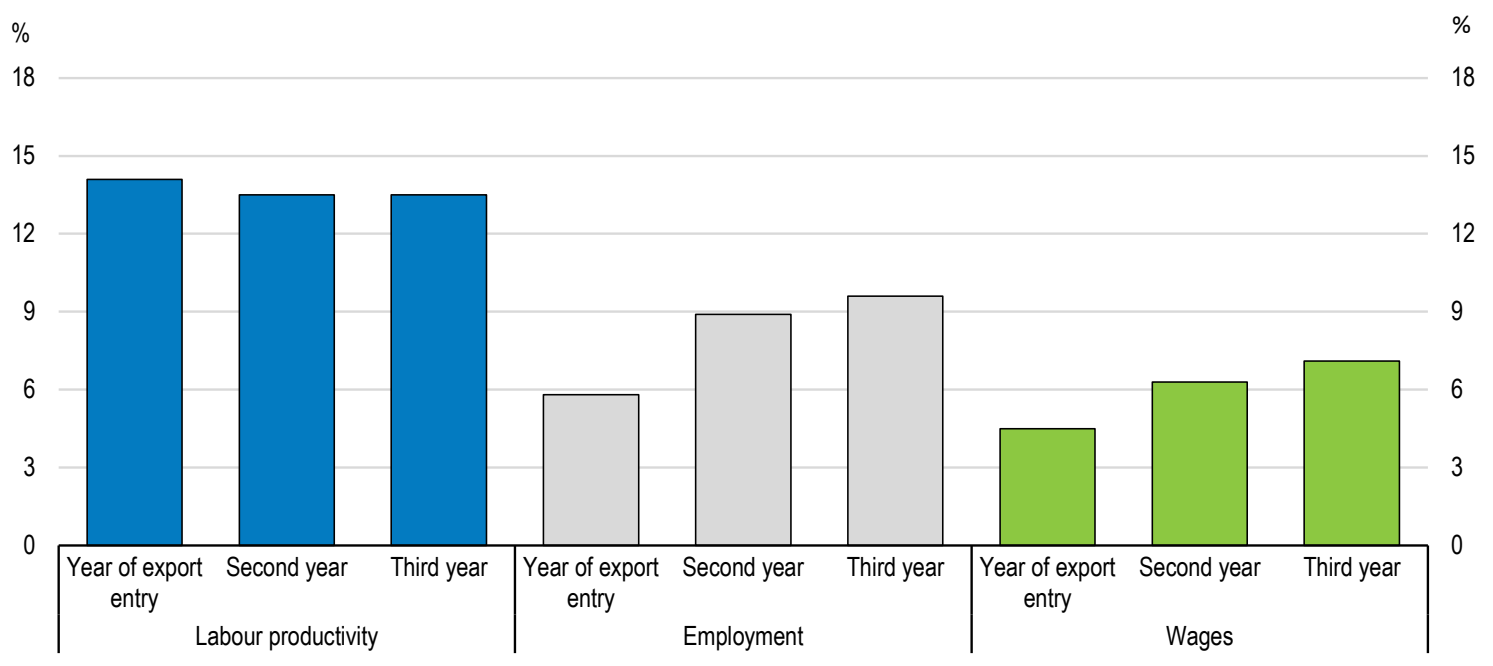

Note: This figure describes the transition of average labour productivity, employment and wages of export entrants (the treated) and matched non-exporters (controls) before and after the export entry. The horizontal axis indicates the time after export entry. 0 corresponds to the year of entry.

Source: Benkovskis et al (2017), "Export and productivity in global value chains: evidence from Latvian and Estonian firms", OECD Economics department working paper, forthcoming.

\section{Facilitating trade by removing unnecessary non-tariff barriers}

With goods crossing borders multiple times, tariffs, transportation costs and costs associated with border procedures become magnified. Firms involved in GVCs are affected not only by costs incurred at their own borders but also by those between third countries situated upstream or downstream (Moïsé and Sorescu, 2015). As a member of the EU single market, there are no tariffs on intra-EU trade, and tariffs on 
third countries are low and managed at the EU level. Estonia scores consistently well in various country rankings for ease of doing business; this favourable performance extends to the costs and time of international trade, which are well below the OECD average. Nevertheless, reforming further trade facilitation in alignment with best international practice could help the country's integration into GVCs and to overcome the small size and remoteness of the economy (Figure 10, Panel A).

- Trade facilitation measures such as cooperation between external and internal border agencies have the potential to encourage forward-type linkages (Moïsé and Sorescu, 2015). Such cooperation can be improved further in Estonia. Currently, there are no staff exchange programmes with partner countries, and coordination with neighbouring countries is low. There seems to be no cooperation between various border agencies and no control delegation to customs authorities in terms of documentation and physical controls.

- The Single Window, grouping documentary requirements of various border agencies, currently under implementation, an equivalent to a one-stop-shop, should be completed. Also, publication of average release and clearance times for goods can help to facilitate trade, as well as expansion of the use of Authorised Operator Programmes, which reduce physical and documentary controls and shorten goods release times.

- Operation of the customs hotline can be strengthened. Information about agreements with third countries, appeal procedures, advance rulings and penalty provisions should be made more accessible. Advance rulings, which increase regulatory certainty, could be used more, especially since they are found to encourage backward-type GVC linkages (Moïsé and Sorescu, 2015).

A similar picture emerges in the context of the services trade restrictiveness index (Figure 10, Panel B). In most sectors, the score is below the OECD average, but not at the minimum. Examining best practices in other countries industry by industry can be inspiring, though a large part of the restrictiveness measured by the index comes down to quotas on foreign workers (this restriction applies after 9 months, i.e. once a temporary work permit expires):

- Estonia's strong ambition for the computer and telecommunications sectors should be reflected in the removal of barriers for them. In computer services, the barriers are mostly due to restrictions on free movement of labour. Since 2017, foreign workers in the ICT sector are exempted from the quota, which is welcome. Nevertheless, there is a requirement that at least half of the board of directors are Estonian residents (that applies to all firms incorporated in the country). Competition-related barriers seem to also exist in telecommunications (e.g. regulation of wholesale access rates).

- In legal and architectural services, there are restrictions on foreign entry and neighbouring Finland (for instance) has lower barriers. Recognition of foreign qualifications in regulated professions is only available for EU countries and to those countries with which Estonia signed a special agreement (OECD, 2015a).

- In maritime and air transport, a considerable number of restrictions apply: foreign equity restrictions, restrictions in the number of non-Estonian board members, and nationality and residency conditions on registering ships and aircraft (OECD, 2015a). 
Figure 10. Scope to improve regulation affecting trade

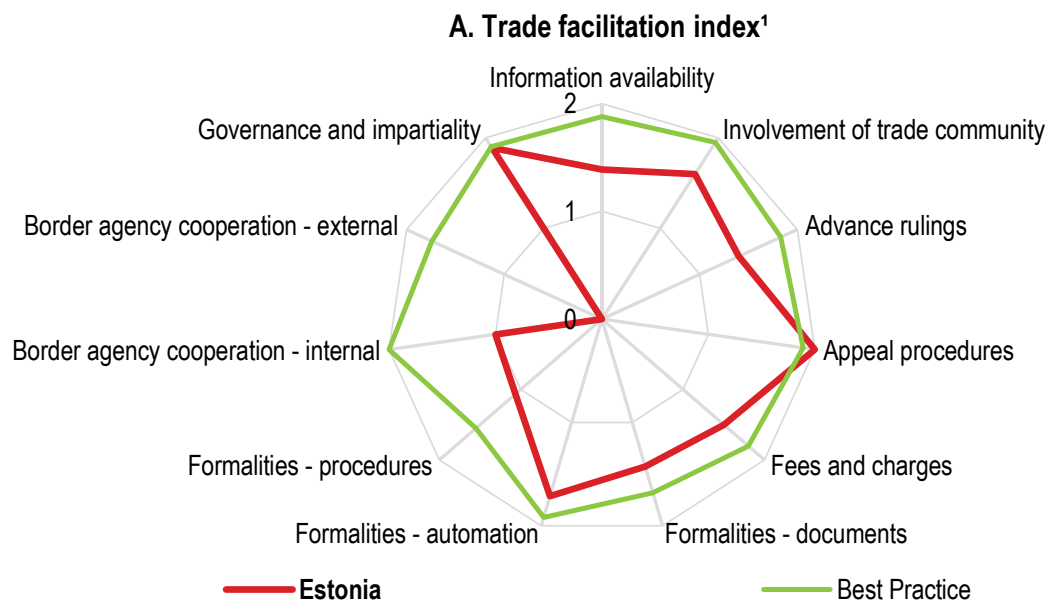

B. OECD Services Trade Restrictiveness Indices (STRI)

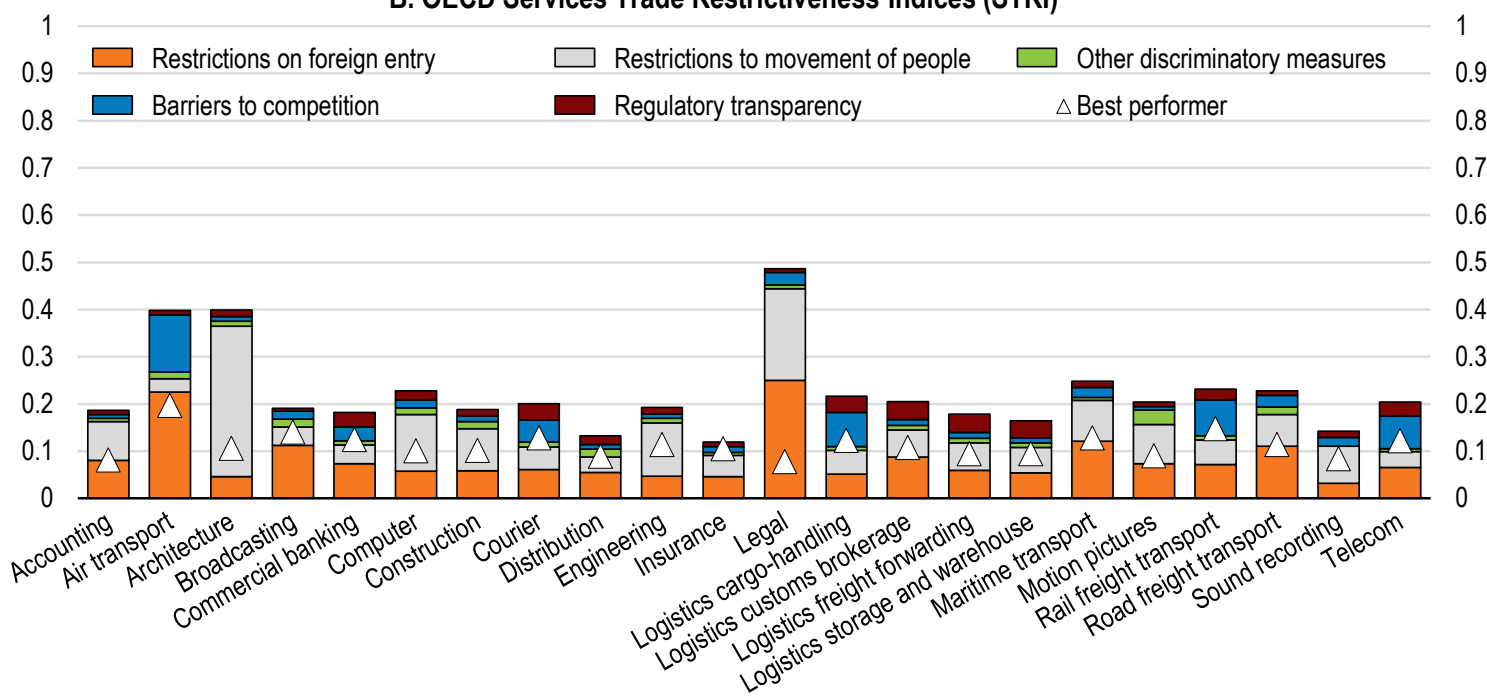

1. Trade facilitation indicator takes values from 0 to 2 , where 2 stands for the best performance that can be achieved.

2. The STRI indices take values between zero and one, one being the most restrictive. They are calculated on the basis of the STRI regulatory database which contains information on regulation for the 35 OECD Members, Brazil, China, Colombia Costa Rica India, Indonesia, Lithuania, Russia and South Africa. The STRI database records measures on a Most Favoured Nations basis. Preferential trade agreements are not taken into account. Air transport and road freight cover only commercial establishment (with accompanying movement of people).

Source: OECD (2017), Trade Facilitation Indicators (database); OECD (2017) Services Trade Restrictiveness Index.

\section{Fostering knowledge diffusion}

To increase the exporting potential as well as to continue climbing up the value chain, Estonian firms need to upgrade their production, i.e. adopt frontier technologies. Ensuring that knowledge transfer and thereby higher productivity continues to spill over from high-productivity firms (often exporters) to the rest of the economy is a policy challenge faced by many economies. This is also true for Estonia, as only a small share of companies seems to engage in innovation (Figure 11). A recent industrial policy paper focuses on digitalisation of the manufacturing sector with a number of tools in the pipeline: developing cooperation platforms between the industry, start-ups and R\&D institutions (so-called hackathons), 
digitalisation audits, long-term loans to encourage R\&D investment, and training for basic digital skills for instance. These are welcome and should be complemented by additional tools to create more fertile ground for the application of research and innovation in the business sector. Also, policies need to reflect that most of the Estonian companies are small and medium-sized which makes economies of scale harder to reach.

Figure 11. Business-driven innovation and spending on R\&D are low

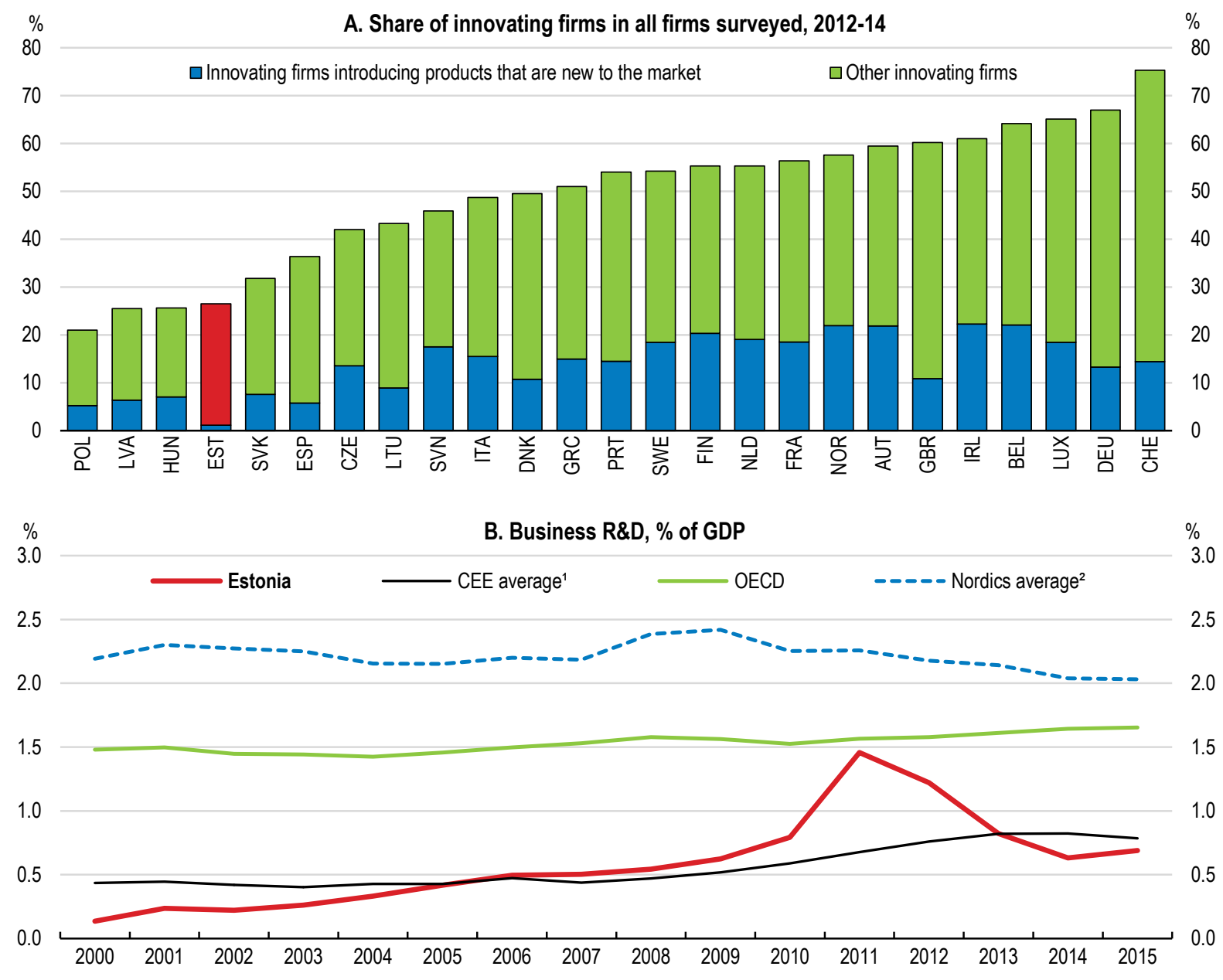

Note: for Panel A: International comparability may be limited due to differences in innovation survey methodologies and countryspecific response patterns.

1. Simple average of Czech Republic, Hungary, Latvia, Poland, Slovak Republic and Slovenia.

2. Simple average of Denmark, Finland and Sweden.

Source: Eurostat (2016), Community Innovation Survey (CIS) 2014; OECD Main Science and Technology Indicators Database.

Estonia is a 'moderate innovator', according to the European Innovation Scoreboard. Innovation output is modest, as evidenced by the number of patent and trademark applications (Figure 12). With total spending of $1.5 \%$ of GDP on R\&D in 2015, it was the third biggest spender on R\&D policies among the CEE countries. However, this was below both the OECD average and Estonia's own national target of 3\% GDP by 2020, of which $1 \%$ of GDP should come from public sources and $2 \%$ of GDP from business. Currently, the spending is shared more or less equally between business and the public sector, though the 
role of the public sector is dominant (as some of the big business R\&D spenders are actually state-owned enterprises).

Figure 12. Innovation activity is limited
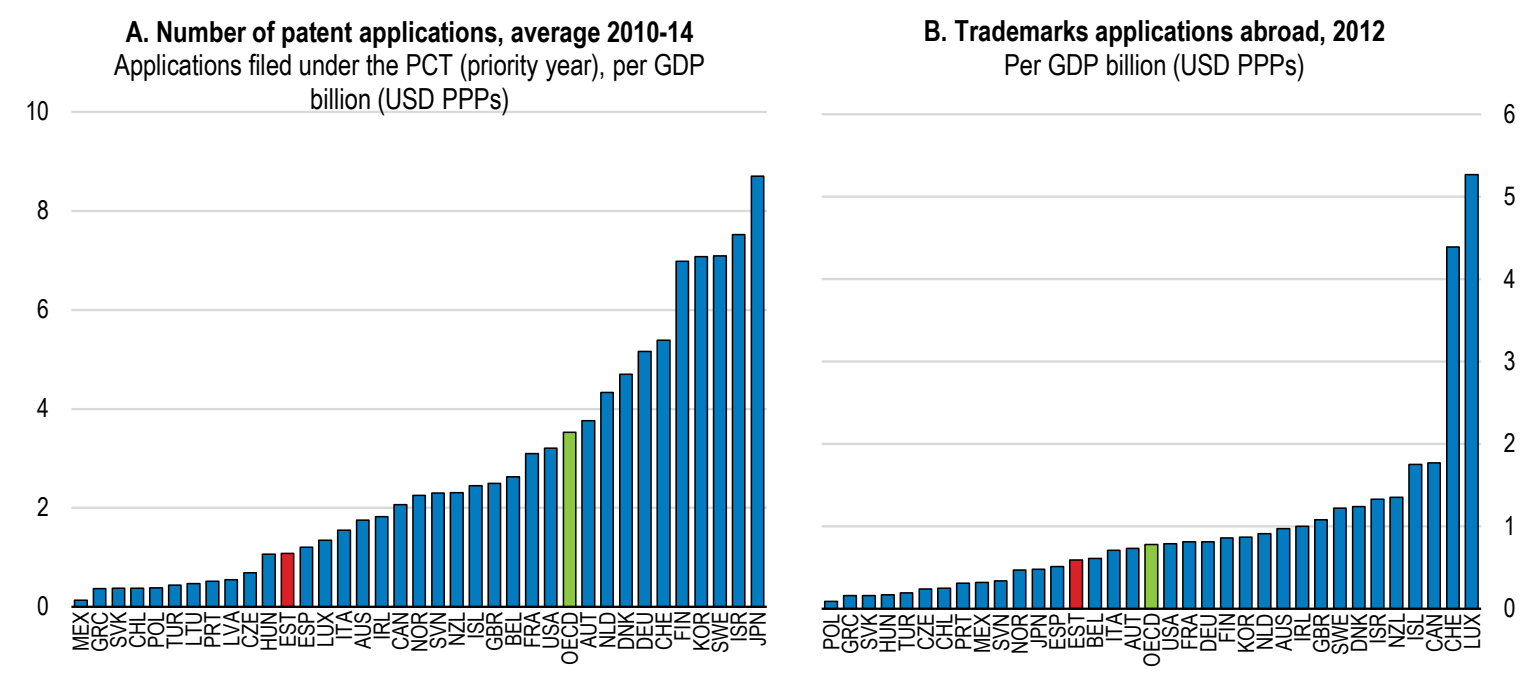

1. Trademarks abroad correspond to the number of applications filed at the USPTO, the OHIM and the JPO, by application date and country of residence of the applicant.

Source: OECD (2017), OECD Patent Statistics; OECD (2016), Science, Technology and Industry Outlook Database.

Business R\&D spending has been consistently below targeted level of $2 \%$ of GDP, despite a highly favourable corporate income tax regime with strong incentives for reinvesting profits (i.e. corporate income tax is levied only on distributed dividends) (Estonian Research Council, 2017) (see Figure 11). Only approximately $10 \%$ of SMEs are introducing new products to the market; while the share among big firms is considerably larger. As illustrated in Figure 11, the situation is similar in the CEE and Baltic peer countries. Estonian companies seem to have limited international and domestic networks and there seems to be little interaction between the export-oriented and domestic-focused sectors (Kattel and Varblane, 2017; Ministry of Economic and Affairs and Communications, 2015a). An earlier study found that foreignowned companies regard the relevance of domestic universities and R\&D organizations, sectoral associations and government organizations as low (Varblane et al, 2011), although their relevance recently has been increasing (Ministry of Economic Affairs and Communications, 2015b).

\section{Low business sector involvement limits potential for knowledge diffusion}

Local stakeholders point to a persistent disconnect between academia and the business community, despite a plethora of policy measures, such as the creation of technology institutes and technology centres, programmes supporting spin-off companies (i.e. companies focused on applying innovation and commercialization of knowledge), innovation and development vouchers and clusters (Karo et al, 2017, Ukrainski et al, 2015). Clusters, i.e. a geographic concentration of firms and research institutions as well as other public and private entities, are used widely across OECD countries and increasingly so in combination with specialization strategies. Estonia has currently 22 clusters, 12 of which receive public support in the following fields: ICT, health, wood industry, defence and security, real estate, energy, wind technologies. 
This seems a high number for such a small country; for instance, Ireland has four main industry clusters. Moreover, it often takes time to reap results, so maintaining public sector commitment in the longrun is important. Experience across OECD countries shows that key factors for success of cluster policies are strong-cooperation, critical human capital mass, research commercialisation, skills enhancement to new areas of demand, strong commitment of the public sector, strong partnership, leadership and social capital (cooperative environment and quality of life) (OECD, 2009). Given the limited human resources in Estonia, achieving critical human capital mass could be challenging (see Chapter 2).

The current innovation policy is strongly shaped by the EU's smart specialisation strategy. It provides significant resources, but has several restrictions that limit its flexibility (in terms of choice of activities, planning and implementation freedom). As a result, an "absorption capacity" approach (i.e. ability to spend the funds) prevails over risk-taking and experimentation in government policy-making (National Audit Office, 2014; Ukrainski et al., 2015; Karo et al., 2017).

The disconnect of academia from the business community manifests itself in a reduced relevance of research for the economy and society (Ruttas-Küttim, 2015). The majority of public R\&D spending is concentrated on areas which differ from those chosen by the major private sector innovators. Indeed, there are good reasons to fund basic research, as it has significantly larger knowledge spillovers compared to applied research (OECD, 2015b). Public funding of applied research in areas such as electronics, forestry, food, mechatronics, automation and other similar fields which would correspond to the leading export sectors has consistently lagged behind. The largest overlap between public and business R\&D focus exists in ICT-related domains (e.g. programming), where the cooperation between academia and the business sector has worked well. Nevertheless, this field is currently suffering from a lack of university graduates, which undermines further prospects for cooperation between business and academia (Karo et al., 2014).

Inclusion of private stakeholders in policy making is rather formal, and horizontal policy-making dominates over sectoral approaches (Karo et al., 2017; Ukrainski et al., 2015). The business sector is represented at the Research and Development Council, a body that has an advisory role. This is welcome as presence of the business sector in high-level advisory bodies helps to create a market perspective in the design and implementation of public research policy (OECD, 2014a). Industry representatives and associations currently play a limited role in design, implementation and feedback and there seems to be limited scope and flexibility for experimentation and changes once public programmes and measures are approved (Ukrainski et al, 2015). The recent industrial policy green paper is hopefully a break from this trend: it has been initiated by the business community, which is welcome. It will be important to maintain the link with the business community while designing concrete policy measures to implement it.

In the academic sector, little emphasis has been put on applied research and capacity for collaboration with the business sector seems low. The evaluation system of R\&D institutions and researchers gives a high weight to publications, resulting in low motivation for cooperation with firms, applied research and innovation (Ruttas-Küttim, 2015). For instance, a sabbatical semester that could be used for gaining experience in the private sector is available every five years for professors and associate professors, but not for senior researchers. As of September 2017, collaboration with industry will receive greater weight in evaluation criteria for distribution of base-line financing, which is welcome. Such incentives are in place for instance in Sweden and Norway (OECD, 2010). Finally, the universities themselves could encourage their staff to cooperate more with the business sector.

\section{Demand side policies can incentivize innovation}

Recent trends in innovation policy place growing emphasis on demand-side policies and instruments (OECD, 2011). Public procurement and demand-side policies were a key determinant in the emergence of several high-technology sectors (e.g. internet, GPS, etc.). Innovation in delivery of public services has the 


\section{ECO/WKP(2017)68}

potential to boost both aggregate productivity and well-being by quality improvements; it can also deliver fiscal savings. Currently, around 35\% of Estonia's total government expenditure happens via public procurement. A demand-side public procurement programme is in place, and although it may be too early to evaluate its reach the take-up so far has been low. Recent projects included procurement for charging stations for electric cars, pre-commercial procurement for devices to disrupt radio waves, and new trafficflow management for ports. The policy lessons drawn from these projects suggest more coordination across ministries and agencies, more focus on long-term goals and greater overall risk-taking in public procurement could increase the chance of success of such programmes (OECD, 2017a).

Demand-side measures require active engagement by the public sector for long periods. Throughout the policy cycle, from policy design and implementation stages to evaluation, these measures include numerous actors and assume the existence of high-quality feedback mechanisms. These instruments may operate at different levels of government, which adds complexity (Lember et al, 2015). While there does not yet seem to be a clear international best-practice to follow, examples such as U.S. or Australian small business innovation research programmes can serve as an inspiration. In the U.S., the program requires public authorities with a certain level of external R\&D budgets to set aside $2.5 \%$ of their funds, that are then pooled to offer competition- based awards to small innovative firms in various R\&D stages (a feasibility study, full R\&D effort and commercialisation stage). Awards are linked to public-sector customer requirements. In the Australian state of Victoria, a market validation programme, aims at yielding $R \& D$ proposals that deliver solutions to public-sector technology requirements (OECD, 2011).

\section{On-going consolidation of public research is welcome}

A number of smaller and independent research organisations are being merged with larger universities. Currently, there are six public universities, eight public institutions of professional higher education and several research institutes (e.g. National Institute of Chemical Physics and Biophysics, IT College, etc.). The on-going merger of research institutions is welcome, but fragmentation of policy focus remains, particularly in terms of its design and coordination. The Ministry of Higher Education and Research liaises with academia. It is the main stakeholder partner, responsible for roughly $80 \%$ of public financing for innovation policy. The Ministry of Economic Affairs and Communication is responsible for most of the remaining public financing, and focuses on innovation, with the business sector as the main interlocutor. Other ministries are responsible for organising and financing about $6 \%$ of R\&D activities (Ruttas-Küttim, 2015). The Research and Development Council under the Prime Minister's Office brings the two ministries together, though there are two subcommittees reflecting the two ministries' division of labour. This is true for funding too: while Enterprise Estonia administers funding for innovation, the Estonian Research Council dispenses funds for academic research. Although a similar spilt exists in a number of OECD countries, it is important to ensure efficient policy dialogue and avoid policy silos.

\section{Putting the productivity debate at the centre of policy making}

A well-designed institution can help to focus policy making on productivity enhancing reforms, as well as improve the quality of the decision process and contribute to evidence-based policymaking (Banks, 2015). A number of OECD countries are addressing the issue of subpar productivity growth by appointing specialised bodies to carry out detailed analysis and highlight areas that necessitate policy attention in order to kick-start productivity growth. For instance, Australia and the Netherlands have a long tradition of such bodies that are permanent and at arms' length from the executive (The Productivity Commission and the CPB), while in a temporary, one year commission appointed by the government investigated the issue recently in Denmark. In Estonia, there is no such unique institution. The authorities are currently considering different options to comply with a recent recommendation of the EU Council to establish productivity boards. While the national context is central in determining the optimal design, mandate, mission and governance of pro-productivity institutions, a recent OECD analysis shows that such 
institutions should also be given sufficient resources, skills, transparency and procedural accountability to fulfil their tasks. Such body should consider both supply-side and demand-side policies (including those proposed by the government) and have policy evaluation functions (Renda and Dougherty, 2017).

\section{Attracting and retaining talent}

Migration can have a positive impact on opening up new trade links and on the adoption of foreign technologies and know-how. Garliardi (2015) finds that skilled immigrants contributed substantially to the innovative performance of recipient areas in Britain. Returning migrants can bring new knowledge and often have higher wages, i.e. higher productivity, than those who stayed. Kauhanen and Kangasniemi (2013) show that return migrants from Finland earn on average 14\% more than comparable earners who did not migrate.

\section{Strong emigration has receded and return migration has risen}

As highlighted in the 2015 Economic Survey, Estonia has been affected by considerable outmigration flows, amounting to $0.2 \%$ of population per year at its peak in 2012. The most popular destinations have been the Nordic countries and the UK which are close and where the wage differential is considerable (OECD, 2015a). As mentioned earlier, emigration of skilled labour has put a pressure on wages in the Central European and Baltic economies, though Estonia has been less affected by brain-drain than its neighbouring Baltic peers (IMF, 2016). The situation has improved since, and in the past two years return migration resulted in positive net migration, with around half of those migrating to the country in 20132016 being Estonian nationals. Nevertheless, labour migration flows from non-EU countries have remained modest (Figure 13). A selective immigration policy towards attracting the high-skilled is in place, but has not been reflected in the composition of migrants (Praxis, 2014). Furthermore, it has not corresponded to actual labour market needs (National Audit Office, 2015).

Figure 13. Labour migration is modest
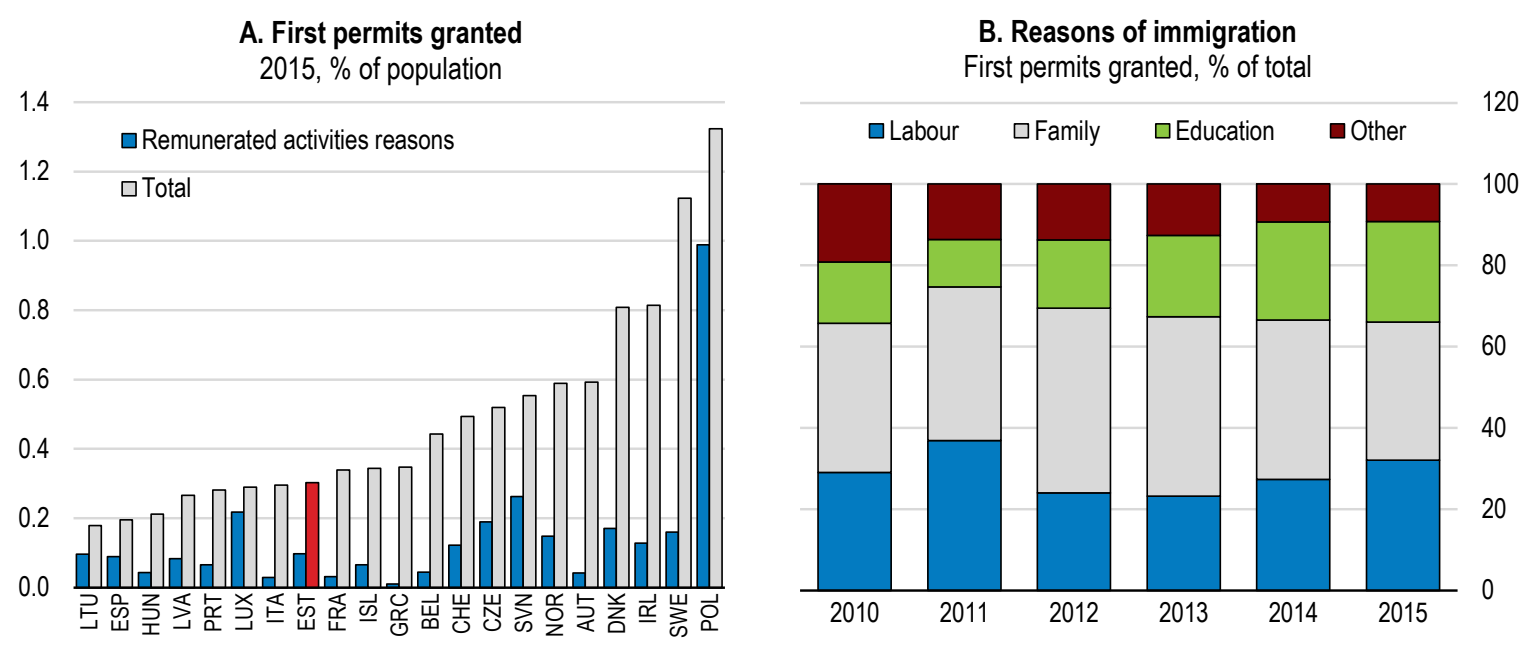

Source: Eurostat, Demography and migration database.

Migration policy framework targets high skilled but so far with only limited success

The immigration policy framework has undergone a number of changes and simplifications recently, but remains complex. Labour migration is employer-led and selective, with a number of conditions 
attached. While there are no restrictions on mobility of EU citizens, a number of routes are available for non-EU nationals, notably two different ones for high-skilled workers (Table 1). Remaining barriers and various exemptions make it difficult to navigate. It is thus welcome that an English-speaking helpline provides information about how to obtain a residence permit. Also dedicated advisors in the police and border guards have been appointed as of March 2017 to provide counselling to employers, entrepreneurs, educational institutions and others intending to employ foreigners in Estonia to facilitate settlement of foreigners in the country.

Salary thresholds are in place, and these vary according to a scheme and profession, with the levels of the thresholds having been rather restrictive (OECD, 2016c). Estimates show that only about 20\% of tertiary educated workers earned incomes above the EU Blue Card threshold (1.25 the average wage) in 2010 and wage statistics of labour migrants during 2005-2013 show that in fact less than $16 \%$ earned double the average wage, i.e. the threshold for the high-skilled scheme (National Audit Office, 2015). Recently, the salary thresholds for residence permit for employment has been lowered to the average wage, and in addition start-up employers are no longer required to meet the salary threshold requirement, which is welcome.

Table 1. Conditions of various labour immigration routes

\begin{tabular}{|c|c|c|c|c|}
\hline & $\begin{array}{l}\text { Residence permit } \\
\text { for employment }\end{array}$ & $\begin{array}{l}\text { High-skilled } \\
\text { scheme ("top } \\
\text { specialist") }\end{array}$ & EU Blue Card & Start-up visa \\
\hline Job offer & Yes & Yes & Yes & $\begin{array}{l}\text { Yes, but also } \\
\text { possible as an } \\
\text { entrepreneur }\end{array}$ \\
\hline Skills threshold & No & Yes & Yes & Varies \\
\hline Labour market test & Yes & No & $\begin{array}{l}\text { Yes, but with } \\
\text { some } \\
\text { exemptions }\end{array}$ & No \\
\hline Shortage occupation list & Yes ( but not used) & No & No & No \\
\hline Numerical limit & Yes (annual quota) & $\begin{array}{l}\text { Yes (annual } \\
\text { quota) }\end{array}$ & $\begin{array}{l}\text { Yes (annual } \\
\text { quota) }\end{array}$ & No \\
\hline $\begin{array}{l}\text { Legal right to an assessment of } \\
\text { formal foreign qualifications }\end{array}$ & Yes & Yes & Yes & Yes \\
\hline Salary threshold & Average wage & $\begin{array}{l}\text { Double the } \\
\text { average wage }\end{array}$ & $\begin{array}{l}1.5 x \text { average } \\
\text { wage with some } \\
\text { exceptions } \\
\text { ( } 1.25 x \text { average } \\
\text { wage) }\end{array}$ & No \\
\hline Family reunification & Yes & Yes & Yes & Yes \\
\hline
\end{tabular}

Source: National Audit Office, Ministry of Interior.

An annual immigration quota on the number of foreigners (both employees and entrepreneurs) is in place, corresponding to $0.1 \%$ of resident population, i.e. 1317 persons in 2017 (Figure 14). Certain groups are excluded, such as researchers, students, selected specialists, family members as well as for instance Japanese and US citizens. As of 2017 such exemption has been extended to start-up employers as well as workers in the ICT sector. The quota has been reached only twice so far (in 2007 and 2016). The recent exemptions add some degree of flexibility. Nevertheless, the quota has a signalling role to potential migrants and employers. Rather than ad hoc adjustments, the necessity to use quotas, in particular when it comes to skilled migrants, should be reviewed or the quotas themselves increased considerably to avoid the risk of being excessively restrictive. It is therefore welcome that a working group on the policy of quota has been set up and it is expected to propose changes to the government by the end of 2017. 
Permanent residency can be gained only once a language test at B1 level is passed, though as of January 2017 a new type of residency permit for permanent settlement in the country is available under which no Estonian language proficiency is required. As in a number of other OECD countries, a labour market test (in the form of an obligation for the employer to notify the Unemployment Insurance Fund of the vacancy and a seven-day waiting period) is in place. The test does not apply to the highly skilled, experts, researchers, graduates of local education institutions and senior management of the most recent start-up scheme but does to the EU Blue Card holders.

Estonia could position itself as a gateway to the EU for skilled third-country foreign nationals, this would be in line with recent start-up visa scheme and more general efforts for international branding of the country (Box 3). Given the low application rate for the Blue Card so far, such migrants stand a better chance of being granted the card in Estonia than in other EU countries where the demand is high or the program doesn't work well. The Estonian labour market would benefit even if such Blue Card holders stay only a couple of years, before moving on to other EU countries. Furthermore, better labour market integration of family migrants could also reduce labour shortages and should be supported by reinforcing activation and training programmes for third country nationals (National Audit Office, 2015).

Figure 14. Annual quota were reached recently, while the number of highly skilled migrants is modest
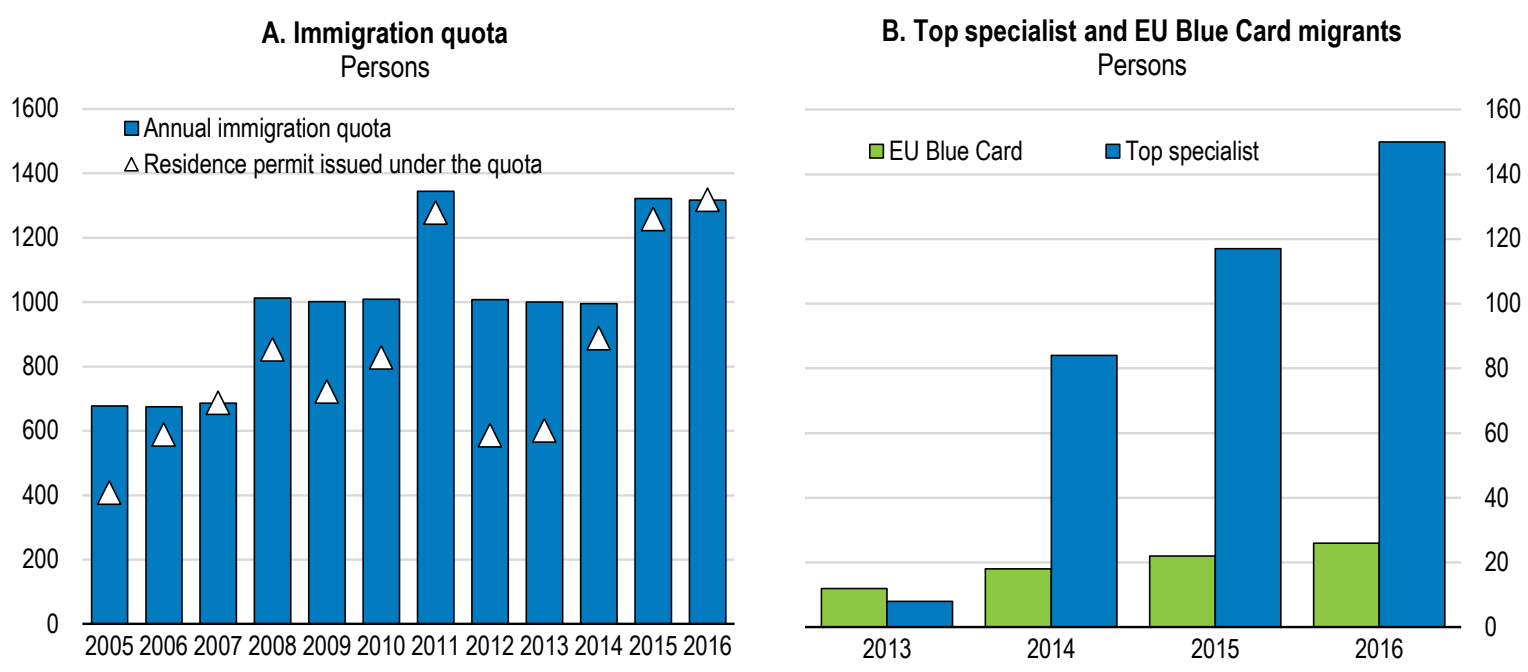

Source: National Audit Office (2017)

Attracting and retaining more international students

Similarly to other Central European countries, Estonia has seen a remarkable rise in the number of international students over the past decade, though starting from a low base (OECD, 2016c). In the academic year of 2016/2017, 3900 non-resident students studied at the Estonian higher education institutions, i.e. $8 \%$ of all tertiary educational enrolment, comparable to the OECD average. The majority of the students come from Finland, Russia and Nigeria. While there are no tuition fees for full-time degree programmes in Estonian, universities generally charge for those in English. Tertiary education could become another exporting article and a source of private funding to the universities.

A fifth of the international students were employed in Estonia following their graduation (within 18 months of degree completion), which is on a par with several OECD countries (OECD, 2016c). Labour market outcomes of EU international students have been better than the non-EU citizens (National Audit 
Office, 2015). One of the contributing factors has been the difference in the time allocated for job search. While there are no conditions of the stay and thus job search of EU citizens, third-country nationals have 6 months following graduation to find employment. The authorities are considering granting graduates of third-country origin a longer period to find a job after completing their studies ( 9 months). This would be welcome as for instance students of third country origin have 12 months in Norway and Finland. Other tools to increase the stay rates of foreign students can include more Estonian language training, traineeship positions in companies, and increasing employer awareness of the benefits of employing foreigners (Praxis, 2014).

\section{Box 3. Building Estonia's brand name}

Efforts to increase awareness of Estonia globally have intensified over the past decade. An internet platform "Study in Estonia" serves as the main starting point for potential international students (studyinestonia.ee); a similar web-portal is available for job vacancies (workinestonia.ee). A start-up visa programme has been launched recently (startupestonia.ee).

Estonia is also making its name for a so-called e-residency scheme (e-resident.gov.ee). Under this scheme, individuals can purchase a government-issued digital identity that includes digital signature and use it for establishing a business in the country. It does not give a right to citizenship, tax residency, a residency permit or entry to Estonia, but is advertised as a tool to reduce intermediary costs when establishing a business location in the country, and to decrease the operational costs of communicating with the authorities (because of the considerable number of $e$ government services).

\section{Making trade work for all}

International trade has been a powerful engine of global economic growth and convergence in living standards. By giving access to a wider variety of goods and services at cheaper prices, it raises well-being and consumers' purchasing power (OECD, 2017b). At the same time, increased specialisation and enhanced international competition leads to offshoring of production, with impact on domestic employment. Openness to trade brings technological change that increases the risk of displacement for low- as well as medium-skilled workers, in particular those with a considerable share of repetitive tasks that can be automatised and substituted with new technologies (Ekholm and Hakkala, 2006). In this context, just over a half of jobs in Estonia have medium- or high- routine intensity (Figure 15).

Workers displaced as a result of offshoring tend to suffer greater earnings losses than others, and such impact is more profound on the low skilled (Hummels et al, 2011). So far, and similarly to other Central European peers, Estonia has been mainly on the receiving end of that offshoring because of its initial labour-cost advantage; however, the cost advantage depletes with income convergence. To ensure that all Estonians benefit from opportunities created by globalisation and high trade intensity, the authorities should focus on two policy areas. Firstly, those who can work need to have the right skills and incentives to participate in the labour market. Secondly, those who are out of the labour market should be supported by an effective and adequate social safety net, conducive to upskilling and maintaining work incentives. 
Figure 15. Routine intensive jobs are at risk of automatisation

Percentage of employment by routine intensity, average over 2000, 2005, 2008-2011

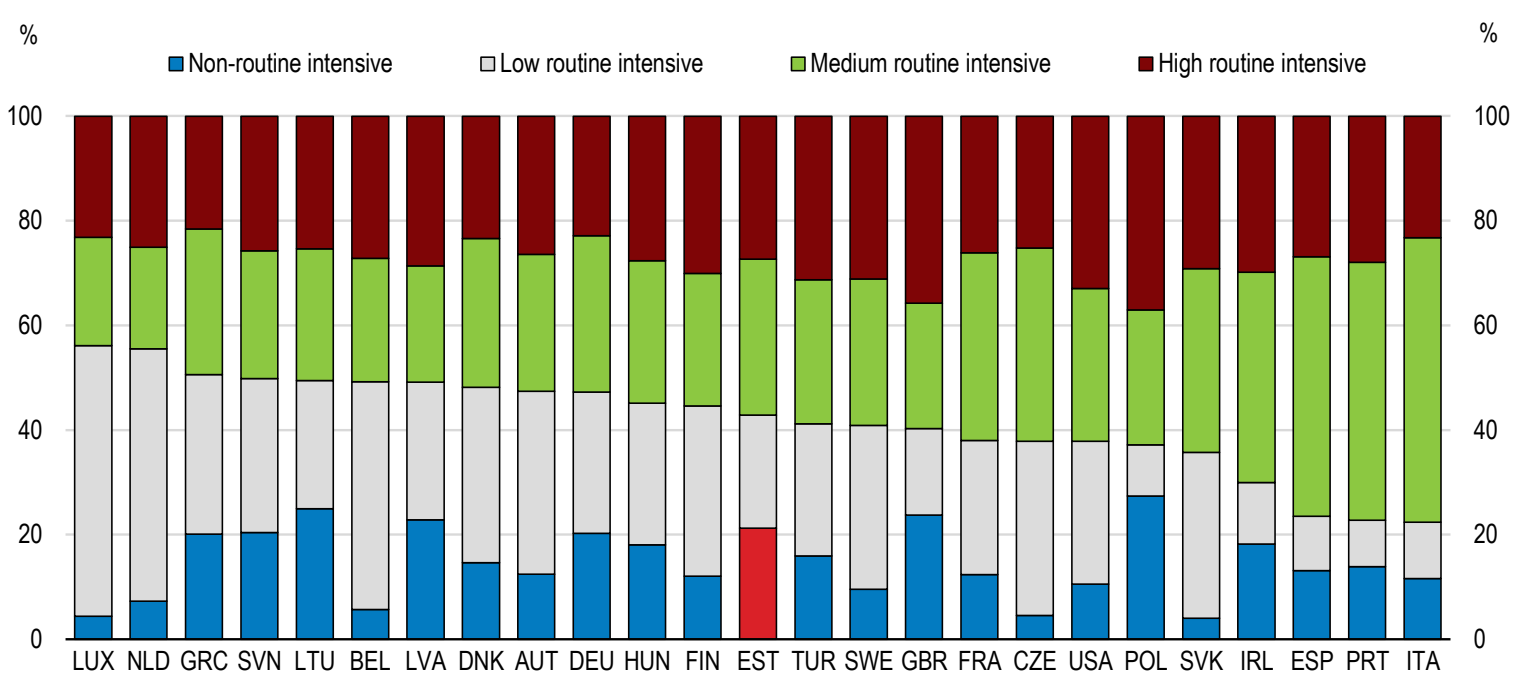

Source: Marcolin et al (2016).

\section{Groups of population left behind}

Estonia was hit hard by the global financial crisis, in particular by the slump in global trade. As detailed in the 2012 Economic Survey, extreme income fluctuations compounded by low social benefits exposed fragile groups of the population to considerable poverty. Groups that were hit particularly hard during the recent downturn were the working-age poor, youth and low-skilled males, because they often have non-standard work contracts, therefore facing the highest risk of job loss, weak attachment to the social security system and few resources for self-insurance (OECD, 2012). Although this was the case in a number of OECD countries, it could be argued that Estonia's low level of social protection contributed to the need for finding income elsewhere, resulting in high emigration following the global downturn.

Even during an economic upswing such as the current one, certain groups of the population are being left behind (Figure 16). 30\% of the working age population is either persistently out of work or has only a weak labour market attachment, and poverty rates are especially high among the jobless and those working part-time (Browne and Pacifio, 2016). Low skills are the common denominator to all those with no or weak labour market attachment. The largest groups have been identified as i) older inactive adults with health limitations, low skills and limited work experience, estimated at around $6 \%$ of population, and ii) those at work but earning very little ("the working poor"), estimated at around 5\% of the population. 
Figure 16. Some groups of population are consistently left behind

$\%$ of reference population at risk of labour market difficulties

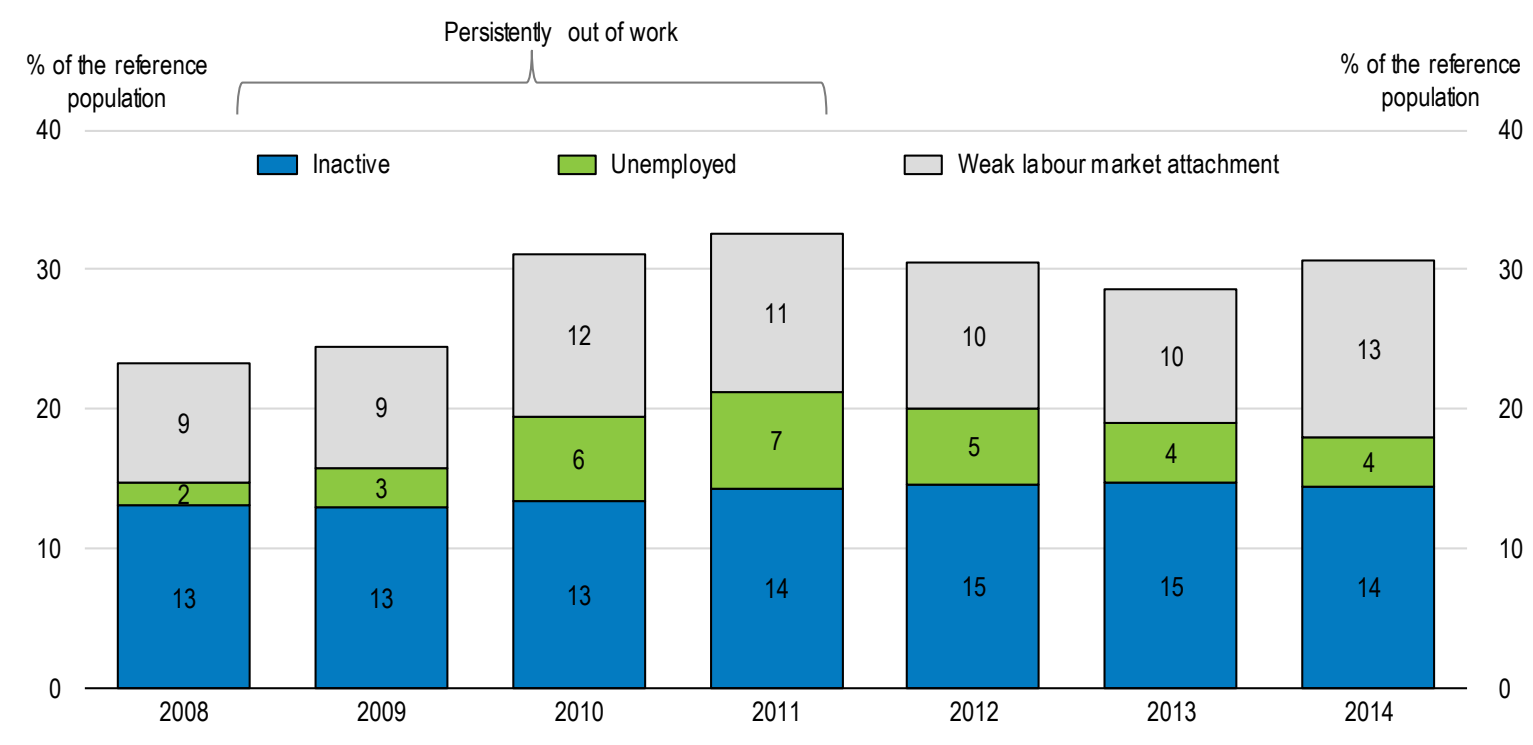

Note: Groups at risk of labour market difficulties are defined as those persistently out of work as well as those with weak labourmarket attachment. Out of work means no employment activity throughout reference period, weak labour market attachment refers to individuals reporting employment activity but working only a limited number of months, working most or all the reference period working 20 hours or a less a week and individuals reporting some activity but negative, zero or near-zero monthly earnings.

Source: Browne and Pacifico (2016), calculations based on EU-SILC 2008-2014.

\section{Providing upskilling opportunities to all}

Lifelong learning is central to maintaining skills and competences relevant to rapidly changing labour market needs, notably in the context of globalisation. Around $30 \%$ of Estonians adults do not have a professional qualification and may not be well equipped to adapt to a fast changing environment. Overall participation in lifelong learning improved significantly in 2016. However, the average number of hours of training per participant is among the lowest in the OECD and training of low-skilled workers remains below the average. Access to upskilling opportunities should be improved further so those currently left behind can find and keep quality jobs.

\section{Enhancing participation of the low-skilled in lifelong learning}

Estonia's lifelong learning strategy sets ambitious targets, including a 20\% participation rate by 2020 (vs. $16 \%$ in 2016) and a reduction in the share of adults without professional qualification to $25 \%$. A number of measures are in place to reach this target (Box 4). However, the take-up of measures targeted to low-skilled workers is likely to be low (Browne, 2017, forthcoming). To enrol in the publicly funded programs, one has to go through a career counselling service at the public employment service (Unemployment Insurance Fund). By definition, those that loose job should contact the fund and can have access to this service, but reaching out to those currently in employment is more challenging. Moreover, due to the patchy coverage of the unemployment benefit (see below), it is unclear that all unemployed actually do register.

To improve the reach and enrolment in life-long learning, training vouchers could be provided to all low-educated workers and directed towards training in core skills (ICT, language) with a view to prepare 
them for a more specialized training, that empirical work shows improved the probability of finding a job. Programmes should also be more targeted at small companies, which are less likely to see the need for training their workforce or to have a training plan (Kitching and Blackburn, 2002). An outreach mechanism targeting small-business managers should be developed to provide them with information and support in identifying appropriate training.

\section{Increasing on-the-job training}

On-the-job training and apprenticeships can provide valuable skills in line with labour market needs. Currently, students have too few opportunities to engage in apprenticeship, and businesses are little involved in the provision of adult education (Figure 17). Despite considerable improvements over the past five years and participation of businesses in the development of occupational profiles in the Vocational Education Training (VET) institutions, only around half of VET provide combined school and work-based vocational learning.

A new programme (PROM) launched in 2015 aims to multiply the number of apprenticeship places by more than five by 2020 and cut the dropout rate to $25 \%$ (from $42 \%$ now). It includes measures to improve the visibility of the system for enterprises and students, provide training for supervisors in schools and in companies, and introduce coordinators in VET schools and working groups to share best practices. Increasing the funding stability of VET institutions and providing better incentives to improve completion rates could also help (Santiago et al., 2016). Additionally, involving the private sector more in provision of educational content could improve the labour market relevance of vocational education and training.

The main obstacle to developing apprenticeship is to find companies offering training opportunities, as a large share of Estonian firms are small with limited resources. Developing a system in which several firms jointly offer apprenticeship training, as recommended in the 2015 Economic Survey (OECD, 2015a), can help to mitigate this problem. To encourage business participation, VET institutions may allocate to companies up to $50 \%$ of the fund paid to the school for the study place. Consideration should also be given to reducing employers' social security contributions or to introducing a lower minimum wage for apprentices.

The Estonian VET schools are successful in enrolling the young and well as adults with various skills levels, which bodes well for life-long learning. However, only about a third of upper secondary education students are enrolled in the VET schools compared to almost a half in other OECD countries. The VET qualifications have a low status compared to general secondary education programmes. This could be partly because the VET schools offer few chances for further progression. Currently, only $10 \%$ of VET graduates go on further to university. Those who wish to do so can follow an additional year at the upper secondary-schools (gymnasiums) to prepare for the university entrance exam. In the Netherlands, Switzerland or Austria, the shares of VET graduates admitted to university are larger, which is helped by post-secondary vocational programmes or dual programmes that provide students with a better preparation for admission to tertiary education (OECD, 2014). 
Figure 17. Businesses are little involved in the provision of vocational education and training

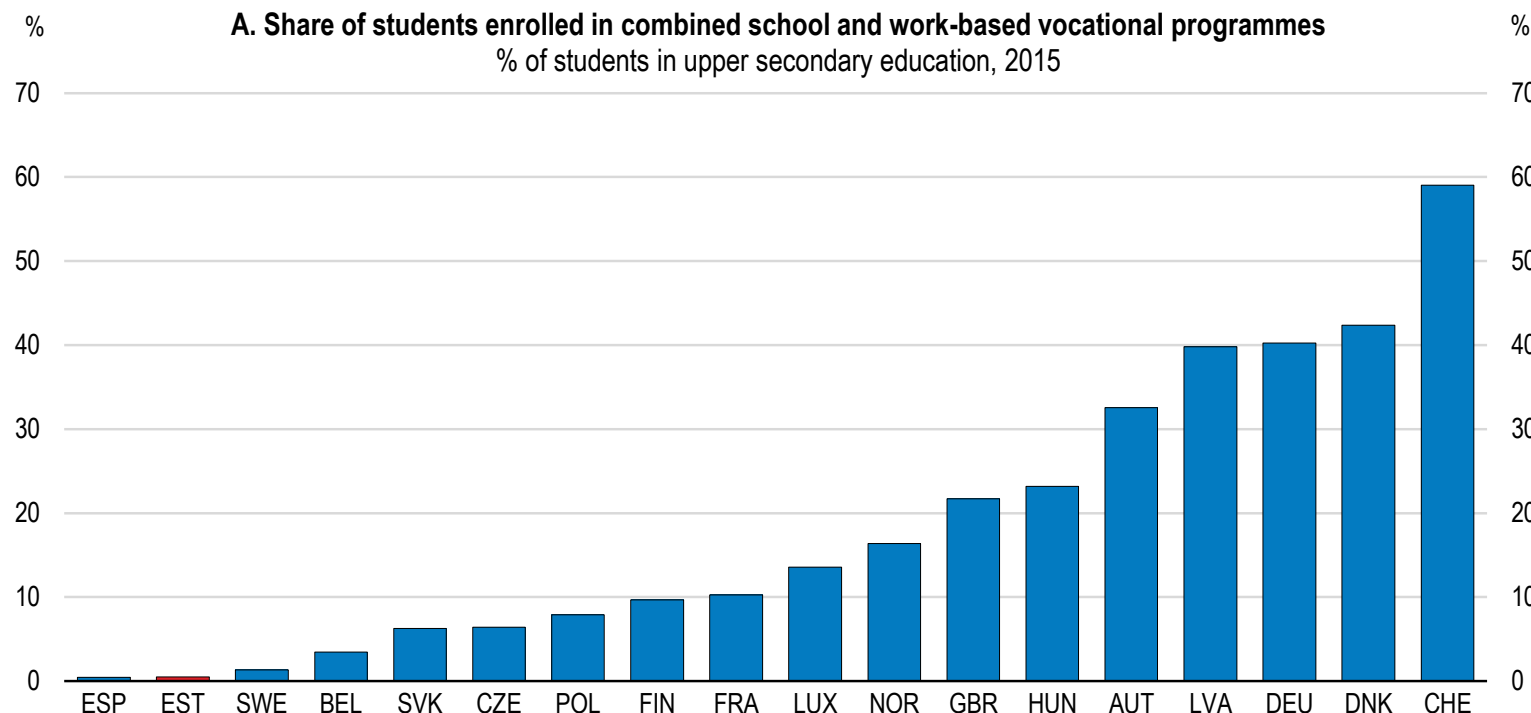

60

50

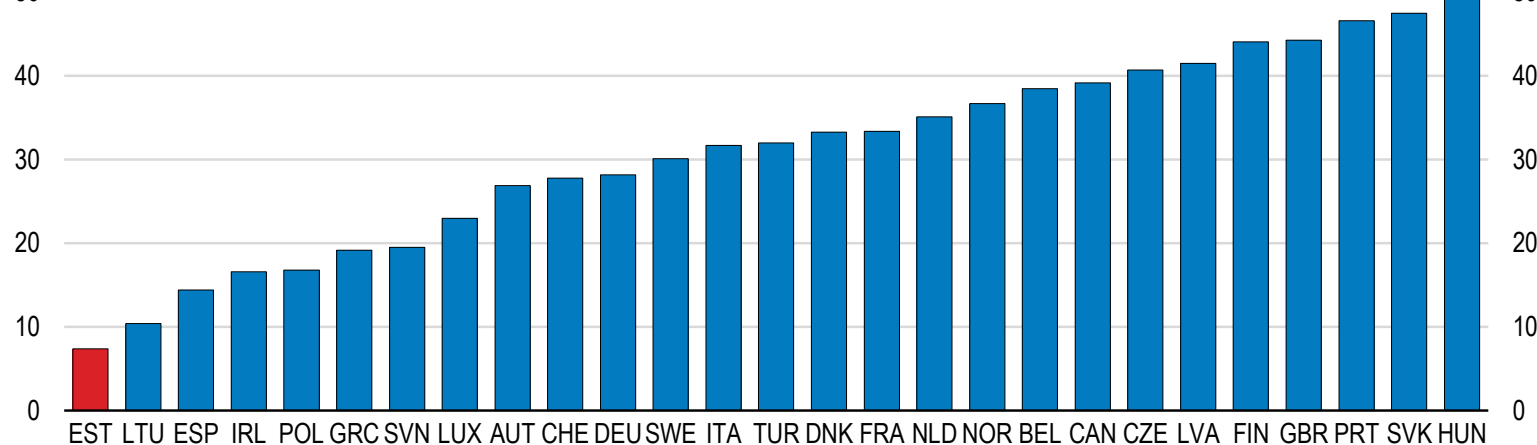

Note: At the upper secondary level (ISCED 3) and the non-tertiary post-secondary level (ISCED 4), "vocational \& prevocational programmes" are divided into "school-based programmes" and "combined school and work-based programmes" on the basis of the amount of training that is provided in school as opposed to training in the work place. Programmes are classified as combined schooland work-based if less than $75 \%$ of the curriculum is presented in the school environment.

Source: Eurostat, Education and training database; Education at a Glance 2016: OECD Indicators.

\section{Income replacement during unemployment is patchy}

International experience suggests that the best way to support displaced workers is through a combination of temporary income support, job search support and measures to improve employability of job seekers (OECD, 2016a). Around a half of the registered unemployed receive some financial support in Estonia: $34 \%$ of the unemployed receive unemployment insurance benefits - this is because eligibility conditions are stricter than in most OECD countries (OECD, 2012) - and some 23\% received 
unemployment assistance (a lower-tier income replacement benefit) in 2016 that is, unlike in most OECD countries, subject to a minimum employment requirement and means-tested.

All unemployed people are entitled to retraining and job placement services. However, due to the stricter eligibility for unemployment benefits, many unemployed do not actually register, and are not reachable by the public employment service to access activation programmes. As a result, the number of people participating in active labour market policies (ALMP) is low and spending on such programmes is modest (Figure 18). Less than 1\% of the labour force participated in ALMPs in 2014, which is less than one quarter of the EU average. The spending on ALMPs is expected to increase significantly in coming years as ALMPs are extended to disability benefits recipients (through the Work Ability Reform), jobseekers above normal retirement age and low-skilled workers (Browne, 2017, forthcoming).

The coverage of the unemployment insurance benefit should be extended to improve participation in active labour market programmes. Wider coverage could lead to increased fiscal costs, but varying the length of the benefit with the economic cycle could offset some of that increase (OECD, 2012). Extending the period of the benefit duration in severe economic downturns and shortening it in the upturns would make the unemployment benefit insurance counter-cyclical and effectively strengthen the automatic stabilisers. Moreover, periods when contributions were made could be accumulated across employment spells without a full reset when in receipt of the benefit. Accumulated entitlement could be reduced in proportion to the benefit duration.

Figure 18. Spending on active labour market policies is low
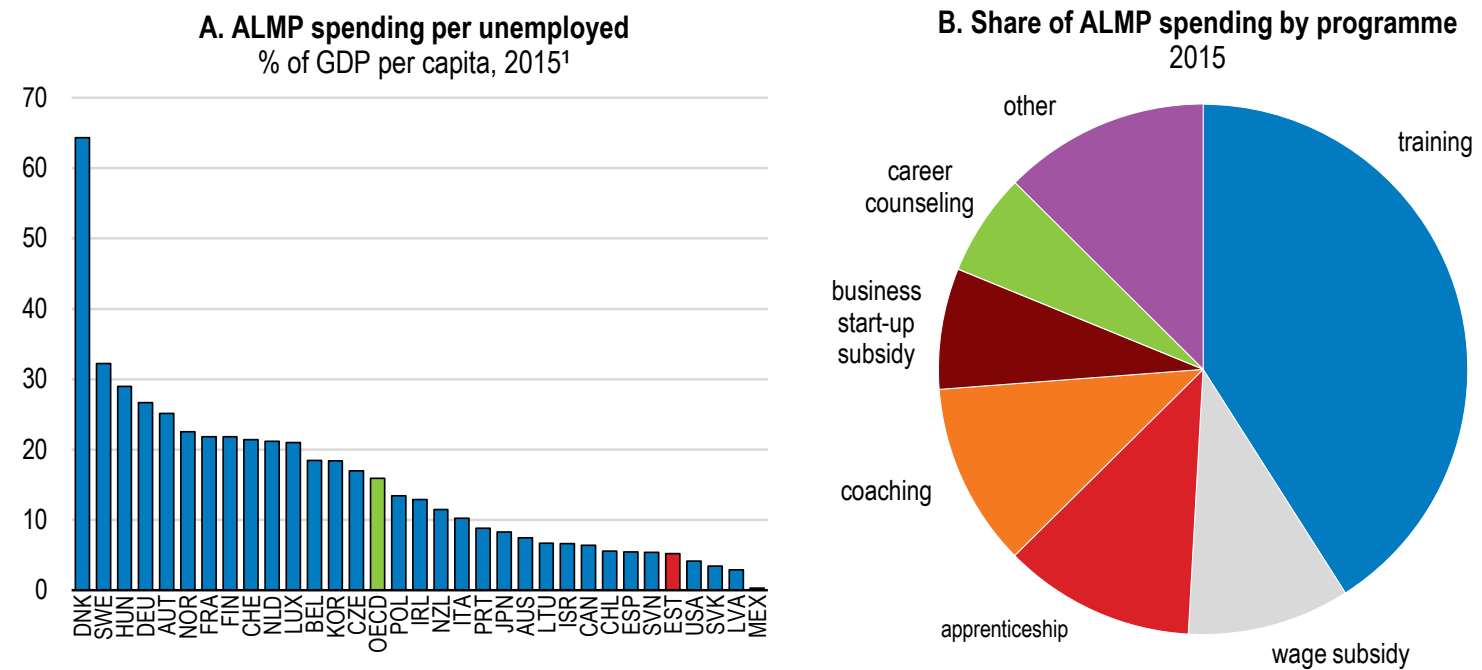

Note: Panel B depicts a breakdown of ALMP spending abstracting from the cost of public employment service itself that represents a half of that spending in Estonia in cross-country comparison in panel $\mathrm{A}$.

1. The OECD aggregate is calculated as an unweighted average of the data shown. Data refer to 2014 for Estonia and New Zealand

Source: OECD Public expenditure and participant stocks on Labour Market programmes database; Estonian Unemployment Insurance Fund. 


\section{Box 4. Active labour market policies in Estonia}

Resources allocated to active labour market policies have increased in recent years, but remain one of the lowest among OECD countries. Estonia spent 5.2\% of GDP per capita per unemployed person in 2014 (vs. 14\% on average in the OECD). Around a half of that spending goes on the public employment service itself, which is double that of the EU average. The staff of the Unemployment Insurance Fund is being increased, which is welcome as their workload is increasing with a roll-out of a new work-ability scheme. Currently, active labour market policies include :

- Public and community work.

- Wage subsidy for employing a long-term unemployed person, young (without a job for more than 6 months or at least 4 months if they have only general secondary education or lower, or no workexperience), a former convict or a person with reduced work ability (if unemployed for at least 6 months). The wage subsidy is a half of the gross salary and usually lasts a maximum of 12 months.

- Work placement - a subsidy for the training for filling a vacant position.

- $\quad$ Training grant for employers for upskilling existing staff (as of May 2017).

- $\quad$ Training of an unemployed person for a specific position that is difficult to fill.

- Job creation subsidy (a part of the salary cost) in Ida-Viru county (north-east region).

- A study allowance for an employed or unemployed person who is pursuing vocational or professional higher education or a bachelor's degree (as of May 2017).

- A business start-up subsidy.

- $\quad$ Reduction of social security contributions for employing people with reduced working abilities.

\section{The social safety net has improved but needs further strengthening}

Over recent years, the poor have benefited from considerable growth in average market incomes, due in part to successive rises in the minimum wage (from EUR 278 in 2011 to EUR 470 in 2017) and from a re-evaluation of subsistence benefits in 2016 (from EUR 90 to EUR 130). A number of redistributive measures are in the pipeline, including a reform of income taxation that is expected to strengthen progressivity in the tax system and incentives to work by raising take-home pay for low-income earners.

Nevertheless, social programmes remain poorly targeted. Most transfers other than old-age pensions are almost equally distributed among the income quintiles and hence provide little redistribution (OECD, 2012). A relative large share of spending is directed to family benefits, while expenditure on social exclusion lags behind (Table 2). Limited resources for social protection are therefore spread thin and do not go to those who most need them (Figure 19). Improved targeting of both benefits and social services, as recommended in the 2012 Economic Survey, would help to reduce poverty at a relatively low cost (OECD, 2012). Estimates of take-up rates for social assistance benefits are relatively low, indicating that some $15-20 \%$ of those eligible for the subsistence benefit and 70-80\% of those eligible for the needs-based family benefit are not receiving it (Võrk and Paulus, 2014; Võrk et al., 2016). This is partly due to the complexity of the social benefit system and underlines the need to streamline the existing benefit schemes. 
ECO/WKP(2017)68

Figure 19. The share of social benefits received by the poor is low and has declined

Share of transfers ${ }^{1}$ received by the lowest decile, working-age population (18-65), \%

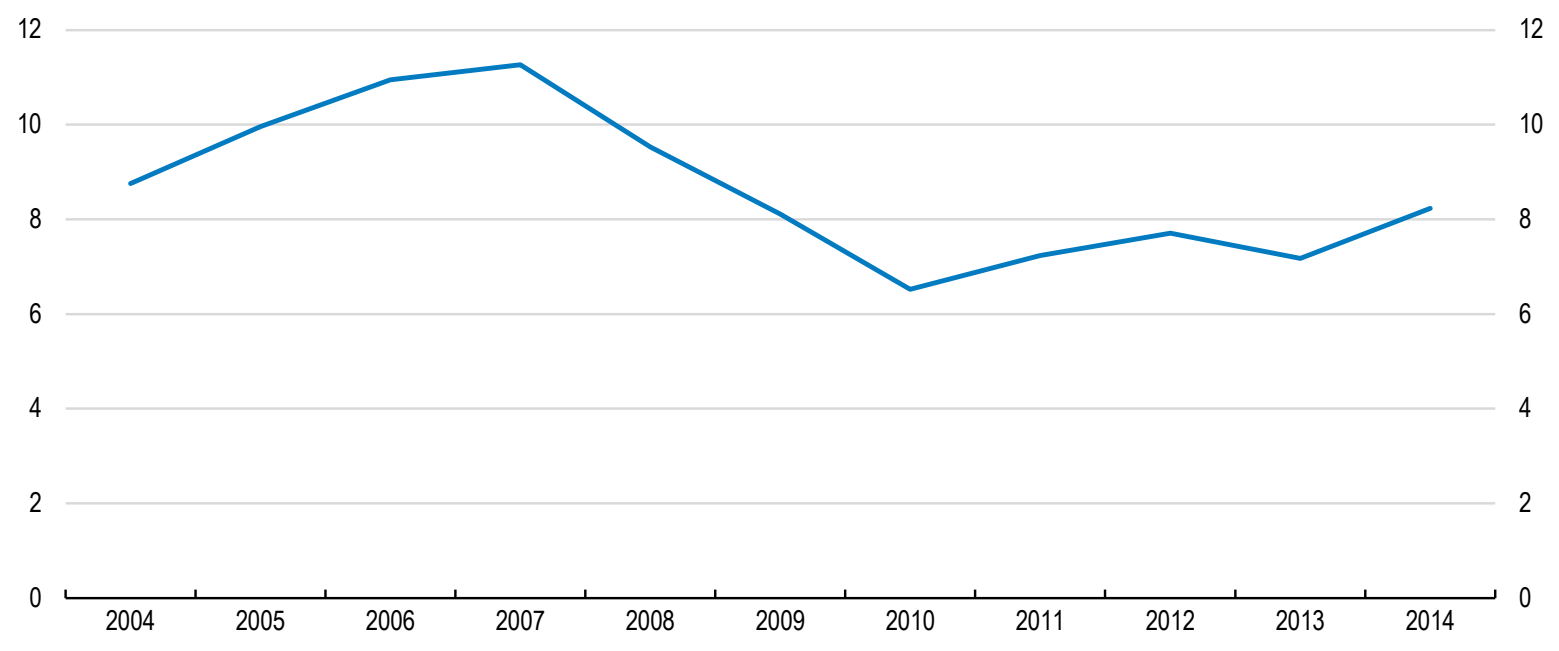

1. Current transfers received from public social security.

Source: Calculations based on OECD Income Distribution Database.

Table 2. Breakdown of social spending

$\%$ of total social protection spending, 2015

\begin{tabular}{lcccccccc}
\hline & $\begin{array}{c}\text { Sickness } \\
\text { and } \\
\text { disability }\end{array}$ & Old age & Survivors & $\begin{array}{c}\text { Family } \\
\text { and } \\
\text { children }\end{array}$ & Unemployment & Housing & $\begin{array}{c}\text { Social } \\
\text { exclusion }\end{array}$ & Other \\
\hline Estonia & 16.4 & 54.5 & 0.5 & 17.9 & 8.3 & 0.2 & 1.0 & 1.2 \\
CEE $^{1}$ & 18.4 & 55.9 & 6.0 & 9.3 & 3.1 & 0.8 & 3.7 & 2.7 \\
Nordics $^{2}$ & 18.4 & 46.3 & 1.5 & 14.6 & 9.4 & 2.1 & 6.0 & 1.6 \\
OECD $^{3}$ & 15.8 & 51.3 & 6.3 & 11.2 & 7.4 & 2.3 & 3.9 & 1.9 \\
\hline
\end{tabular}

1. Unweighted average of Czech Republic, Hungary, Latvia, Lithuania, Poland, Slovak Republic, and Slovenia.

2. Unweighted average of Denmark, Finland, Sweden.

3. Unweighted average of available OECD countries.

Source: OECD National Accounts database.

While indexation rules apply for the calculation of some benefits (e.g. public pensions, the minimum and maximum rate of unemployment insurance benefit), others, such as subsistence and family benefits, are not automatically adjusted to price or wage developments. As a result, their values have eroded substantially in real terms. Automatic indexation would avoid erosion of the benefits over time and strengthen effectiveness of the social protection system. It should at least partly reflect income growth in the economy to ensure a fairer sharing of the catch-up in living standards between those employed and those not or no longer active. 


\section{Box 5. Recommendations for capitalising on trade}

Removing unnecessary non-tariff barriers

Key recommendations

- $\quad$ Complete a one-stop shop for administrative formalities.

- Improve access to information on trade regulation (e.g. agreements with third countries and appeal procedures).

\section{Other recommendations for removing unnecessary non-tariff barriers}

- Review remaining barriers to entry in services, such as telecommunications, legal and architecture.

- Expand the Authorised Operator programme that allows certified trade operators to move goods faster.

\section{Attracting and retaining talent}

\section{Key recommendation}

- Relax annual quotas, and simplify conditions for the work permits of skilled workers.

Other recommendations for attracting and retaining talent

- $\quad$ Exclude high-skilled migrant workers from the annual quota.

- $\quad$ Extend job search period for non-EU international students.

- Reinforce activation and training programmes for third-country nationals that arrived via family reunification.

\section{Fostering knowledge diffusion}

\section{Key recommendations}

- $\quad$ Give more weight to cooperation with the private sector when allocating funds to public R\&D institutions.

- $\quad$ Establish an independent body to advise on policies to raise productivity.

\section{Other recommendations for improving knowledge transfer}

- Maintain the link with the business community when designing concrete policy measures to digitalize the manufacturing sector.

- Encourage academics to participate in private sector innovation and research activities as part of their curricula.

- $\quad$ Make a greater use of public procurement of innovation, for instance to address pressing societal issues.

Making trade work for all

\section{Key recommendations}

- Increase subsistence benefits, while maintaining strong work incentives.

- Relax eligibility conditions for unemployment benefits, not least to improve participation in active labour market measures.

Other recommendations for making trade work for all

- $\quad$ Vary the unemployment benefit rates over the business cycle.

- Introduce automatic indexation of social benefits that will in part reflect wage growth in the economy.

- Reduce the cost for firms that take on apprentices by cutting employers' social security contributions or introducing a specific lower minimum wage. 


\section{REFERENCES}

Amiti M., Konings, J. (2007), “Trade Liberalisation, Intermediate Inputs, and Productivity: Evidence from Indonesia”, American Economic Review, Vol. 97/5, pp. 1611-1638.

Appelt S. et al. (2016), "R\&D Tax incentives: Evidence on Design, Incidents and Impact, OECD Science", Technology and Industry Policy Papers, No. 32, OECD Publishing, Paris. http://dx.doi.org/10.1787/23074957.

Aw, B. Y., Robert, M. J. and Winston, T. (2007), "Export Market Participation, Investments in R\&D and Worker Training, and the Evolution of Firm Productivity". The World Economy, Vol. 30/1, pp. 83104.

Baldwin R. (2012), “Trade and Industrialisation after Globalisation's Second Unbundling: How Building and Joining a Supply Chains are different and why it matters, Globalisation in an age of Crisis: Multilateral Economic Cooperation in the twenty-first century" in R. Feenstra and R. Taylor (eds.), University of Chicago Press.

Banks, C. (2015), "Institutions to promote pro-productivity policies: Logic and lessons", OECD Productivity Working Papers No. 1, http://oe.cd/GFP.

Benkovskis K. et al. (2017), "Export and Productivity in Global Value Chains: Evidence from Latvian and Estonian firms", OECD Economics department working paper, forthcoming.

Benkovskis K. and J. Woertz (2016), “Cost competitiveness: A dangerous obsession, CEPR's policy portal”, www.voxeu.org, http://voxeu.org/article/cost-competitiveness-obsession.

Bernard, A. B., \& Jensen, J. B. (1999), "Exceptional exporter performance: Cause, effect, or both"? Journal of International Economics, Vol. 47/1, pp. 1-25.

Blalock, G., P. J. Gertler (2004), "Learning from Exporting Revisited in a less developed setting", Journal of Development Economics, Vol. 75, pp. 397-416.

Browne J. and Pacifico (2016), Faces of Joblessness in Estonia: Anatomy of Employment Barriers, OECD Publishing, Paris. http://www.oecd.org/els/soc/Faces-of-Joblessness-in-Estonia.pdf

Browne J. (2017), Assessing Activating and Enabling benefits and Services in the EU - Country Policy Paper for Estonia, OECD Publishing, Paris, forthcoming.

Coe D. T., E. Helpman, A.W. Hoffmaister (2008), “International R\&D Spillovers and Institutions", IMF Working paper, International Monetary Fund, Publications Services, Washington.

De Backer, K. and S. Miroudot (2013), "Mapping Global Value Chains", OECD Trade Policy Papers, No. 159, OECD Publishing, http://dx.doi.org/10.1787/18166873.

De Loecker, J. (2007), "Do Exports Generate Higher Productivity? Evidence from Slovenia”, Journal of International Economics, Vol. 73, pp. 69-98.

Eesti Pank (2016), “Estonian Competitiveness Report 2016”, Estonian Central Bank, Tallinn. 
Eesti Pank (2017), “Estonian Competitiveness Report 2017”, Estonian Central Bank, Tallinn.

Estonian Research Council (2017), Estonian Research 2016, Estonian Research Council, Tallinn.

Ekholm, K., K. Hakkala, (2006), "The Effect of Offshoring on Labour Demand: Evidence from Sweden”, CEPR Discussion Paper, No. 5648, www.cepr.org.

European Commission (2015), "Stairway to Excellence - Country Report Estonia", JRS Science and policy report, Luxembourg publication office of the European Union.

European Commission (2016), "Country Report Estonia 2016”, Commission staff working document, European Commission, Brussels.

Foster-McGregor, N., Isaksson, A., Kaulich, F. (2014), "Importing, Exporting and Performance in SubSaharan African Manufacturing Firms", Review of World Economics/Weltwirtschaftliches Archiv, Vol. 150/2, pp. 309-336.

Gagliardi, L. (2015), "Does Skilled Migration foster Innovative Performance? Evidence from British local areas", Papers in Regional Science, Vol. 94, pp. 773-794. http://dx.doi.org/10.1111/pirs.12095.

Greenaway, D. and Kneller, R. (2007), Firm heterogeneity, exporting and foreign direct investment. The Economic Journal, 117: F134-F161. http://dx.doi.org/10.1111/j.1468-0297.2007.02018.x

Hijzen, A. and P. Swaim (2007), “Does offshoring reduce industry employment?”, National Institute Economic Review, Vol. 201/1, pp. 86-96.

Hummels, D. et al. (2011), "The Wage Effects of Offshoring: Evidence from Danish Matched Worker-firm data", NBER Working paper, No. 17496.

IMF (2013), "Trade Interconnectedness - The World with Global Value Chains", IMF Policy Paper, in Lipsey, R. E. and F. Sjöholm (2004), - "Foreign Direct Investment, Education, and Wages in Indonesian Manufacturing", Journal of Development Economics, Vol. 73, pp. 415-422.

IMF (2017), "Republic of Estonia - Selected issues", IMF Country report No. 17/10, International Monetary Fund, Publications Services, Washington D.C.

IMF (2016), "Emigration and Its Economic Impact on Eastern Europe", IMF Staff Discussion Note SDN/16/17, International Monetary Fund, Publications Services, Washington D.C.

Karo, E. et al. (2014), Nutikas spetsialiseerumine: kas Eesti teadus-, arendus- ja innovatsioonipoliitika kuldvõtmeke aastail 2014-2020. Riigikogu Toimetised, Vol. 29, pp. 116-136. Available at: https://goo.gl/cAkY1B.

Karo, E.; R. Kattel, A. Cepilovs (2017), "Can smart specialization and entrepreneurial discovery be organized by government? Lessons from the less-developed regions" in Radosevic, S.; A. Curaj, L. Andreescu, R. Gheorgiou, I. Wade (Ed.). Smart Specialization Theory and Practice: Regional Planning and Development. Elsevier Science BV, in press.

Kattel, R. and U. Varblane (2017), Eesti ettevõte tootmis- ja innovatsioonivõrgustikud in Estonian Development Report 2017, forthcoming. 
Kauhanen, M., and M. Kangasniemi (2013), Returns to return migration: wage premium of Estonian return migrants from Finland, Labour Institute for Economic Research, Helsinki.

Keller, W., S. R. Yeaple (2009), "Multinational Enterprises, International Trade, and Productivity Growth : Firm-level Evidence from the United States", The Review of Economics and Statistics, Vol. 91/4, pp. 821-831.

Kitching J. and R. Blackburn (2002), The nature of training and motivation to train in small firms, Small business research centre, Kingston University.

Kowalski, P., et al. (2015), "Participation of Developing Countries in Global Value Chains: Implications for Trade and Trade-Related Policies", OECD Trade Policy Papers, No. 179, OECD Publishing, Paris.

Lember, V. et al. (2015), "Relevance of Research and Development and Innovation Policy for the real economy. Research and Innovation", Policy Monitoring Programme (TIPS) Report No. 5.2. http://tips.ut.ee/index.php?module=32\&op=1\&id=3701.

Lopez-Gonzalez, J., P. Kowalski and P. Achard (2015), "Trade, Global Value Chains and Wage-income Inequality", OECD Trade Policy Papers, No. 182, OECD Publishing, Paris, http://dx.doi.org/10.1787/18166873

Mare D. C., R. Fabling, S. Stillman (2011), "Immigration and Innovation", IZA Discussion Paper No. 5686, April 2011, Institute for the study of Labour, Bonn.

Marcolin, L., S. Miroudot and M. Squicciarini (2016), "GVCs, Jobs And Routine Content Of Occupations", OECD Trade Policy Papers, No. 187, OECD Publishing, Paris, http://dx.doi.org/10.1787/18166873.

Masso J., J. Jarve and M. Kaska (2015), Low and top performers of information processing skills in Estonia, $3^{\text {rd }}$ thematic report, Ministry of Education, Tallinn.

Masso, J. and P. Vahter (2015), "Exporting and Productivity: the Effects of Multi-product and MultiMarket Export Entry" Scottish Journal of Political Economy, Vol. 62, No. 4, September 2015. http://onlinelibrary.wiley.com/doi/10.1111/sjpe.12077/full

Masso, J., P. Vahter (2016), "Knowledge Transfer from Multinationals through Labour Mobility: Learning from Export Experience", University of Tartu, Faculty of Economics and Business Administration Working Paper No. 99.

Masso, J., T. Roolaht, U. Varblane (2010), "Foreign Direct Investment and Innovation in Central and Eastern Europe: Evidence from Estonia", The University of Tartu Faculty of Economics and Business Administration Working Paper, No. 67-2010, http://dx.doi.org/10.2139/ssrn.1557036.

Ministry of Economic Affairs and Communications (2015a), Sulling: "Estonian dairy producers have signed their first contracts with a Japanese corporation", https://www.mkm.ee/en/news/sullingestonian-dairy-producers-have-signed-their-first-contracts-japanese-corporation.

Ministry of Economic Affairs and Communications (2015b), "Eesti ettevõtete uuendusmeelsus ja innovatsiooni toetamise võimalused", Innovation Studies, No. 24, https://www.mkm.ee/sites/default/files/inno_24.pdf. 


\section{ECO/WKP(2017)68}

Miroudot S. (2016), "GVC and trade in value added: an initial assessment on the impact on jobs and productivity", OECD Trade Policy Papers, No. 190, OECD Publishing, Paris, http://dx.doi.org/10.1787/18166873

Moïsé, E. and S. Sorescu (2015), "Contribution of Trade Facilitation Measures to the Operation of Supply Chains", OECD Trade Policy Papers, No. 181, OECD Publishing, Paris, http://dx.doi.org/10.1787/18166873

National Audit Office (2015), Overview of the state's migration policy choices, National Audit Office, Tallinn.

National Audit Office. (2014), Impact of innovation support measures on the competitiveness of companies. National Audit Office, Tallinn, http://www.riigikontroll.ee/Riigikontrollipublikatsioonid/Auditiaruanded/tabid/206/Audit/2340/lang uage/et-EE/Default.aspx

OECD (2009), Clusters, Innovation and Entrepreneurship, OECD Publishing, Paris. http://dx.doi.org/10.1787/9789264044326-en

OECD (2010), Performance-based Funding for Public Research in Tertiary Education Institutions: Workshop Proceedings, OECD Publishing, Paris. http://dx.doi.org/10.1787/9789264094611-en.

OECD (2011), Demand-side Innovation Policies, OECD Publishing, Paris. http://dx.doi.org/10.1787/9789264098886-en.

OECD (2012), Economic Surveys: Estonia, OECD Publishing, Paris. http://dx.doi.org/10.1787/22212302.

OECD (2013), Interconnected Economies: Benefiting from Global Value Chains, OECD Publishing, Paris. http://dx.doi.org/10.1787/9789264189560-en.

OECD (2014a), OECD Science, technology and Industry Outlook 2014, OECD Publishing, Paris. http://dx.doi.org/10.1787/19991428.

OECD (2014b), Skills Beyond School: Synthesis Report, OECD Reviews of Vocational Education and Training, OECD Publishing. http://dx.doi.org/10.1787/9789264214682-en.

OECD (2015a), Economic Surveys: Estonia, OECD Publishing, Paris. http://dx.doi.org/10.1787/22212302.

OECD (2015b), OECD Innovation Imperative, OECD Publishing, Paris. http://dx.doi.org/10.1787/9789264239814-en

OECD (2016a), Trade by enterprise characteristics database, OECD Publishing, Paris. http://dx.doi.org/10.1787/glob-enterp-data-en.

OECD (2016b), Trade in Employment Database, STAN Databases, OECD Publishing, Paris

OECD (2016c), Migration outlook, OECD Publishing, Paris. http://dx.doi.org/10.1787/migr_outlook2016-en.

OECD (2016d), Education at a Glance 2016, OECD Publishing, Paris. http://dx.doi.org/10.1787/eag-2016en. 
OECD (2016e), Getting skills right: Assessing and anticipating changing skills needs, OECD Publishing. http://dx.doi.org/10.1787/9789264252073-en.

OECD (2017a), Public procurement for Innovation: Good Practices and Strategies, OECD Publishing, Paris, forthcoming.

OECD (2017b), Economic Outlook, OECD Publishing, Paris. http://dx.doi.org/10.1787/eco_outlookv2017-1-en.

Praxis (2014), Talent attraction and retention in Estonia, Praxis, Tallinn.

Renda, A. and S. Dougherty (2017),"Pro-Productivity Institutions: Learning From National Experience”, OECD Productivity Working Papers, 2017-07, OECD Publishing, Paris. http://dx.doi.org/ $10.1787 / \mathrm{d} 1615666-\mathrm{en}$

Rusticelli, E. et al. (2017), "Going Local: A Regional Perspective on International Trade, Labour Markets and Inequality", OECD Economics Department Working Papers, OECD Publishing, Paris (forthcoming).

Ruttas- Küttim R., (2015), Stairway to excellence - Country report Estonia, JRS Science and Policy report, European Commission, Brussels.

Santiago, P., et al. (2016), OECD Reviews of School Resources: Estonia 2016, OECD Reviews of School Resources, OECD Publishing, Paris, http://dx.doi.org/10.1787/9789264251731-en.

Ukrainski, K. et al. (2015), Eesti teadus- ja arendustegevuse ning innovatsiooni strateegia 2007-2013 täitmise analüüs. Available at: https://goo.gl/FMm65F.

van Biesebroeck, J. (2005), "Exporting raises productivity in sub-Saharan African manufacturing firms", Journal of International Economics, Vol. 67, pp. 373-91.

Varblane, U. (Ed.) (2011), Otsesed välisinvesteeringud Eesti majanduses, Tartu: Tartu Ülikooli Kirjastus.

Võrk, A. and A. Paulus (2014), EUROMOD Country Report: Estonia, Colchester: University of Essex.

Võrk, A., A. Paulus, and C. Leppik (2016), EUROMOD Country Report: Estonia 2011-2016. Colchester: University of Essex.

Wagner J., 2007. "Exports and Productivity: A Survey of the Evidence from Firm-level Data," The World Economy, Wiley Blackwell, vol. 30(1), pages 60-82, 01. 